\title{
ENSIALIC TECTONIC SETTING OF THE ARCHAEAN RIO DAS VELHAS GREENSTONE BELT: Nd AND Pb ISOTOPIC EVIDENCE FROM THE BONFIM METAMORPHIC COMPLEX, QUADRILÁTERO FERRÍFERO, BRAZIL
}

\author{
MAURÍCIO A. CARNEIRO*, WILSON TEIXEIRA**, IRNEU MENDES DE CARVALHO JUNIOR" \\ \& RINALDO AFRANIO FERNANDES****
}

\begin{abstract}
RESUMO POSICIONAMENTO ENSIALICO DO GREENSTONE BELT RIO DAS VELHAS: EVIDENNCIAS ISOTÓPICAS DE Nd E Pb DO COMPLEXO METAMORFICO BONFIM, QUADRILATERO FERRIFERO, BRASIL O Complexo Metamorfico Bonfim é um dos vdrios fragmentos de idade arqueana que constituem a crosta sialica da porção meridional do Craton do Sao Francisco, situado na regiao leste do territbrio brasileiro. A porcão setentrional do Complexo, localizada na regiao do Quadrilátero Ferrifero, consiste de oito unidades litoestratigraticas, das quais seis sao neoarqueanas e formadas por gnaisses de composiçao trondhjemitica a granitica, granitoides intrusivos e diques anfiboliticos. As outras duas, uma e do Mesoproterozóico e a outra, provavelmente, do Fanerozoico. A nucleação primitiva deste complexo teve inicio no Mesoarqueano, há cerca de $3200 \mathrm{Ma}$ atras, como sugerido pelas idades modelo $\mathrm{Sm}-\mathrm{Nd}\left(\mathrm{T}_{\mathrm{DM}}\right)$ e pela herança isotopica de $\mathrm{Pb}$ encontrada no nucleo de zircoes dos gnaisses estudados. No entanto, esta crosta primitiva foi severamente retrabalhada no decorrer do Evento Tectonotermal Rio das Velhas (2780 - $2700 \mathrm{Ma}$ ). No decorrer deste evento, além do metamorfismo impresso nas rochas do Complexo Metamorfico Bonfim Setentrional, a crosta sialica e o greenstone belt Rio das Velhas, na regiao do Quadrilatero Ferrifero, foram palco de magmatismo calcio-alcalino e tholeiitico. As caracteristicas geologicas deste evento, suportadas pela assinatura geoquimica das rochas do Complexo Metamorfico Bonfim Setentrional, sugerem um ambiente tectonico similar a aquele das margens convergentes atuais. Pequenos corpos e diques de rochas graniticas, com idade em torno de $2703 \pm 24 / 20 \mathrm{Ma}$, datadas pelo metodo U-Pb em zircões, intrudem o Complexo Metam6rfico Bonfim Setentrional, encerrando a evolução tectonica neoarqueana da regiao estudada. Durante o Proterozoico, as rochas do Complexo Bonfim foram sucessivamente afetadas por processes metam6rficos de baixo grau que promoveram reajustes isotopicos variaveis nos sistemas $\mathrm{Rb}-\mathrm{Sr}$ (rocha total) e $\mathrm{K}-\mathrm{Ar}$ (em minerais). Finalmente, a partir dos dados petrologicos, geoqufmicos e geocronologicos dispomveis, apresenta-se um modelo tectonico global para explicar a evolução tectonica do Quadrilatero Ferrifero do Meso- ao Neoarqueano. Este modelo envolve os seguintes ambientes e processes geológicos: margens convergentes, plumas mantelicas, mistura de magmas, acumulação de material mafico na base da crosta sialica arqueana e sua fusao parcial, injeção e contaminação magmatica, tectonica extensional, formacão de bacias, oceanização, magmatismo granitico, calcio-alcalino, mafico e ultramafico, fechamento e inversao de bacia sedimentar durante o Evento Tectonotermal Rio das Velhas.
\end{abstract}

Palavras chaves: Neoarqueano, Greenstone Belt, Complexo Metamorfico, Geocronologia, Geoquimica, Quadrilatero Ferrifero, Evento Tectonotermal Rio das Velhas.

\begin{abstract}
The Bonfim Metamorphic Complex is one of the sialic fragments that make up the Archaean crust of the Southern Sao Francisco Craton, eastern Brazil. The northern part of the Bonfim Metamorphic Complex, located in the Quadrilatero Ferrifero region, was investigated on the basis of petrology, geochemistry and $\mathrm{U}-\mathrm{Pb}$ and $\mathrm{Sm}-\mathrm{Nd}$ geochronology. This complex comprises eight lithostratigraphic units, six of them NeoArchaean in age, composed of trondhjemitic to granitic gneisses, intrusive granitoids and amphibolites. The other two units are Mesoproterozoic and probably Phanerozoic mafic dikes. The origin of rock protoliths of the Bonfim Metamorphic Complex goes back to the $3200 \mathrm{Ma}$ ago, as suggested by inherited U-Pb age components and $\mathrm{Sm}-\mathrm{Nd}\left(\mathrm{T}_{\mathrm{DM}}\right)$ crust formation ages. The main evolution of the Northern Bonfim Metamorphic Complex was associated with the Rio das Velhas Tectonothermal Event (2780 - $2700 \mathrm{Ma})$ that correlates with major NeoArchaean events in the Southern Sao Francisco Craton. The Rio das Velhas event, in the Northern Bonfim Metamorphic Complex, is characterized by widespread metamorphism, calc-alkaline (tonalite bodies) and tholeiitic magmatism within both the sialic crust and Rio das Velhas greenstone belt. The geological features together with geochemical signatures suggest a convergent margin setting for the Neoproterozoic evolution, which final steps are represented by an intrusive granite activity dated by U-Pb zircon at $2703 \pm 24 / 20$ Ma. During the Proterozoic, the NeoArchaean crust was affected by thermotectonic overprints, under low-grade facies metamorphic conditions, as suggested by resetting of the $\mathrm{Rb}-\mathrm{Sr}$ (whole rock), and $\mathrm{K}-\mathrm{Ar}$ (mineral) isotopic systems. Finally, from the petrological, geochemical and geochronological data, this paper presents a global tectonic model for the geological evolution from the Meso- to NeoArchaean in the Quadril\&tero Ferrifero region. This model comprises the following geological setting and processes: active margins, mantelic plumes, magma mixing and mingling, partial melting of the lower Archaean sialic crust by mantelic underplating, extensional tectonics and ocean basin generation, ultramafic, mafic, calc alkaline and granite magmatism, tectonic inversion and closing basin during the Rio das Velhas Tectonothermal Event.
\end{abstract}

Keywords: NeoArchaean, Greenstone Belt, Metamorphic Complex, Geochronology, Geochemistry, Quadrilátero Ferrifero, Rio das Velhas Tectonothermal Event.

INTRODUCTION The Quadrildtero Ferrífero (QF), located in the southern part of the Sao Francisco Craton (SSFC, Fig. 1) is well known for the iron and gold deposits hosted within supracrustal rocks. Most geological investigations in the region are focused on the economically important su- pracrustal sequences (Dorr II 1969, Ladeira 1980, Schorscher et al. 1982, Mascarenhas et al. 1984, Marshak \& Alkmim 1989, Castro 1994). However, there has been very limited study of the crystalline basement (e.g. Herz 1970, Gomes 1985,Gomes 1986, Machado et al. 1992, Machado et al. 1996,

* Departamento de Geologia, Escola de Minas, Universidade Federal de Ouro Preto, Morro do Cruzeiro, Ouro Preto, Minas Gerais, 35400-000, Brazil. E-mail: mauricio@degeo.ufop.br

** Departamento de Geologia Geral - Institute de Geociencias - Universidade de Sao Paulo - P.O. Box 11348 -CEP $05422-970$ - Sao Paulo - Brazil. E-mail: wteixeir@usp.br

*** Departamento de Geologia, Escola de Minas, Universidade Federal de Ouro Preto, Morro do Cruzeiro, Ouro Preto, Minas Gerais, 35400-000, Brazil. PIBIC Grants Research. E-mail:imcjr@hotmail.com.br; nafer@hotmail.com.br 
Teixeira et al. 1996, Noce 1995). Recent geological studies (Carneiro 1992, Carneiro \& Teixeira 1992, 1993, Carneiro et al. 1993,1994,1995,1996,1997,1998, Machado \& Carneiro 1992), have inferred the presence of an old sialic crust and a probably convergent margin environment for the Rio das Velhas Tectonothermal Event (RVTE) dated between 2780 $2700 \mathrm{Ma}$. In this paper, we present an integrated interpretation of the existing petrologic, geochemical, and geochronological information available for the NeoArchaean sialic crust of the $\mathrm{QF}$, especially from the northern part of the Bonfim Metamorphic Complex (NBMC, Fig. 2). Additionally we discuss the implications of these data for the NeoArchaean geological evolution of the QF and SSFC.

Geological Setting Three main lithologic assemblages occur in the QF (Fig. 1): the Minas Supergroup (MS), the Rio das Velhas Greenstone Belt (RVGB), and the Metamorphic Basement Complex (MBC). The MS (Dorr II 1969) of Paleoproterozoic age (Machado et al. 1992, Babinski et al. 1995, Machado et al. 1996), lies unconformably on both the RVGB and the MBC, and consists of thick banded-iron deposits as well as clastic and carbonate metasedimentary units. The RVGB (Dorr II 1969, Schorscher et al. 1982) is a NeoArchaean greenstone belt hosting important gold deposits. Both the MS and RVGB have been tightly folded and strongly sheared, and regionally metamorphosed to greenschist facies (Ladeira \& Viveiros 1984). The regional basement metamor- phic complex (BMC) crops out in several distinct domes such as the NBMC (Figs. 1,2), and has metamorphic grade ranging from greenschist to granulite facies (Herz 1970, Gomes 1985, 1986, Gomes \& Miiller 1987).

\section{The NeoArchaean lithologic units of the NBMC}

The NBMC comprises six lithologic units (Table 1; Fig. 2) from the NeoArchaean time (Carneiro 1992, Machado \& Carneiro 1992, Carneiro et al. 1998). The two youngest NBMC units (Conceição de Itagua Metadiabase e Santa Cruz Diabase) are not discussed in this paper (more information about these two units are reported in Carneiro et al. 1998). Four units of the NBMC are felsic and two are mafic in composition. The felsic units are the Alberto Flores and Souza Noschese Gneisses (Herz 1970), the Samambaia Tonalite, and the Brumadinho Granite (Carneiro 1992, Carneiro et al. 1997). The two mafic units are the Paraopeba and Candeias Amphibolites (Carneiro 1992, Carneiro et al. 1997, 1998). In the next paragraphs we summarize the main geological and petrographic features of NeoArchaean NBMC units, from oldest to youngest, according to the field relations and, basically, U-Pb geochronological evidence.

The Alberto Flores Gneiss (AFG) is a banded gray gneiss. This is the oldest unit of the NBMC as indicated by field relations and geochronological $\mathrm{U}-\mathrm{Pb}$ results.

The AFG has a granoblastic texture, and consists of plagioclase, microcline, and quartz with minor biotite, apatite,

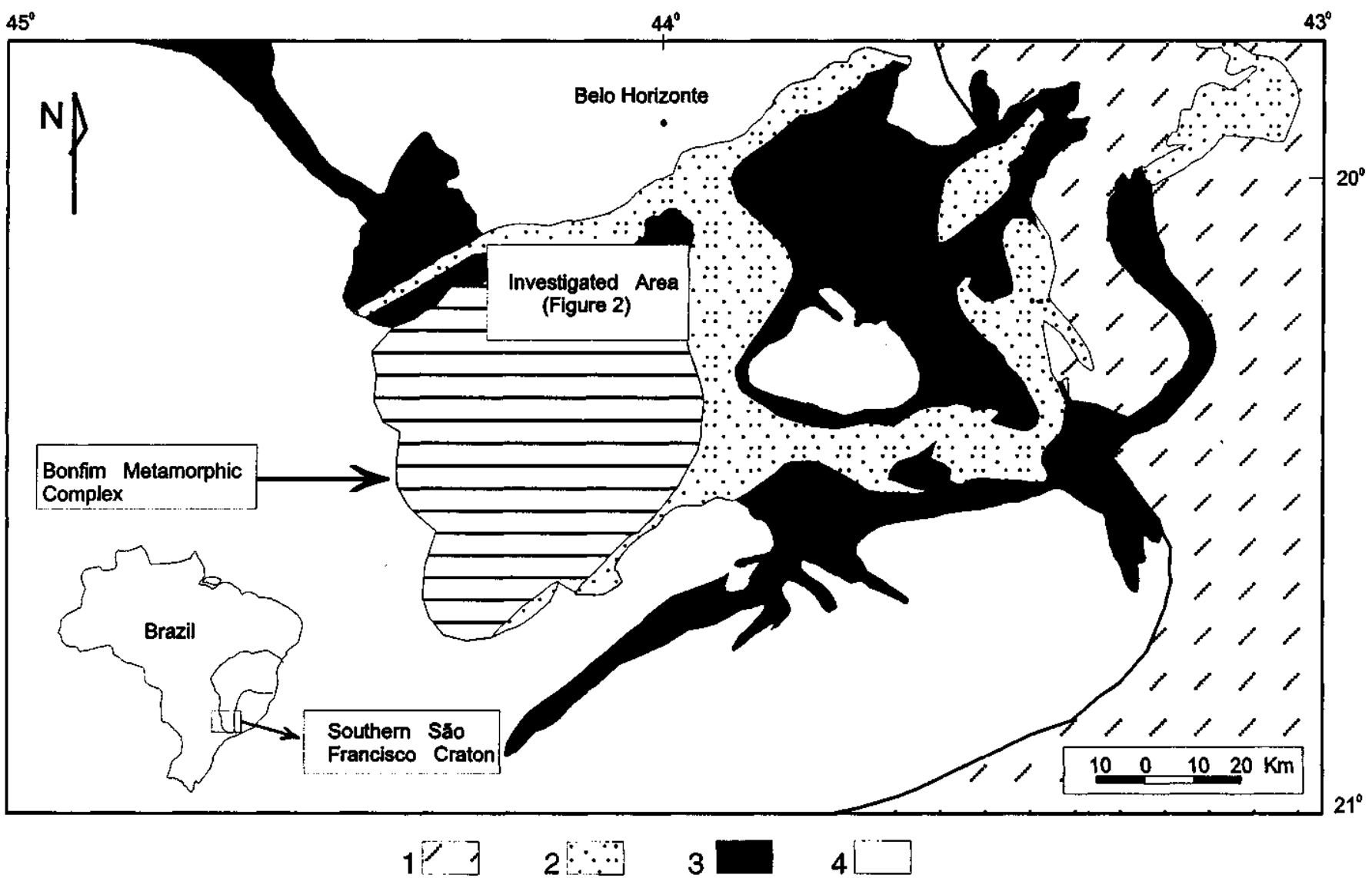

Figure 1 - Simplified geological map of the Quadrilatero Ferrifero, southern portion of the São Francisco Craton (after Carneiro 1992, Carneiro et al. 1997, 1998). Boxed area corresponds to the Northern Bonfim Metamorphic Complex. Keys: 1 - Neoproterozoic reworked terranes; 2 - Minas Supergroup (Paleoproterozoic); 3 - Rio das Velhas Greenstone Belt (NeoArchaean); 4 - Mesoto NeoArchaean Metamorphic Complex of Southern São Francisco Craton, in part reworked in the Paleoproterozoic. Figura 1 - Mapa geologico simplificado do Quadrilatero Ferrífero, porção sul do Craton do Sao Francisco Craton (segundo Carneiro 1992, Carneiro et al. 1997, 1998). Area emoldurada corresponde ao Complexo Metamorfico Bonfim. 1 - Terrenos Neoproterozoicos retrabalhados; 2 - Supergrupo Minas (Paleoproterozoico); 3 - Greenstone Belt Rio das Velhas (NeoArqueano); 4 - Complexos metamdrficos Meso- a NeoArqueanos do sul do Craton do Sao Francisco, em parte retrabalhados no Paleoproterozoic. 


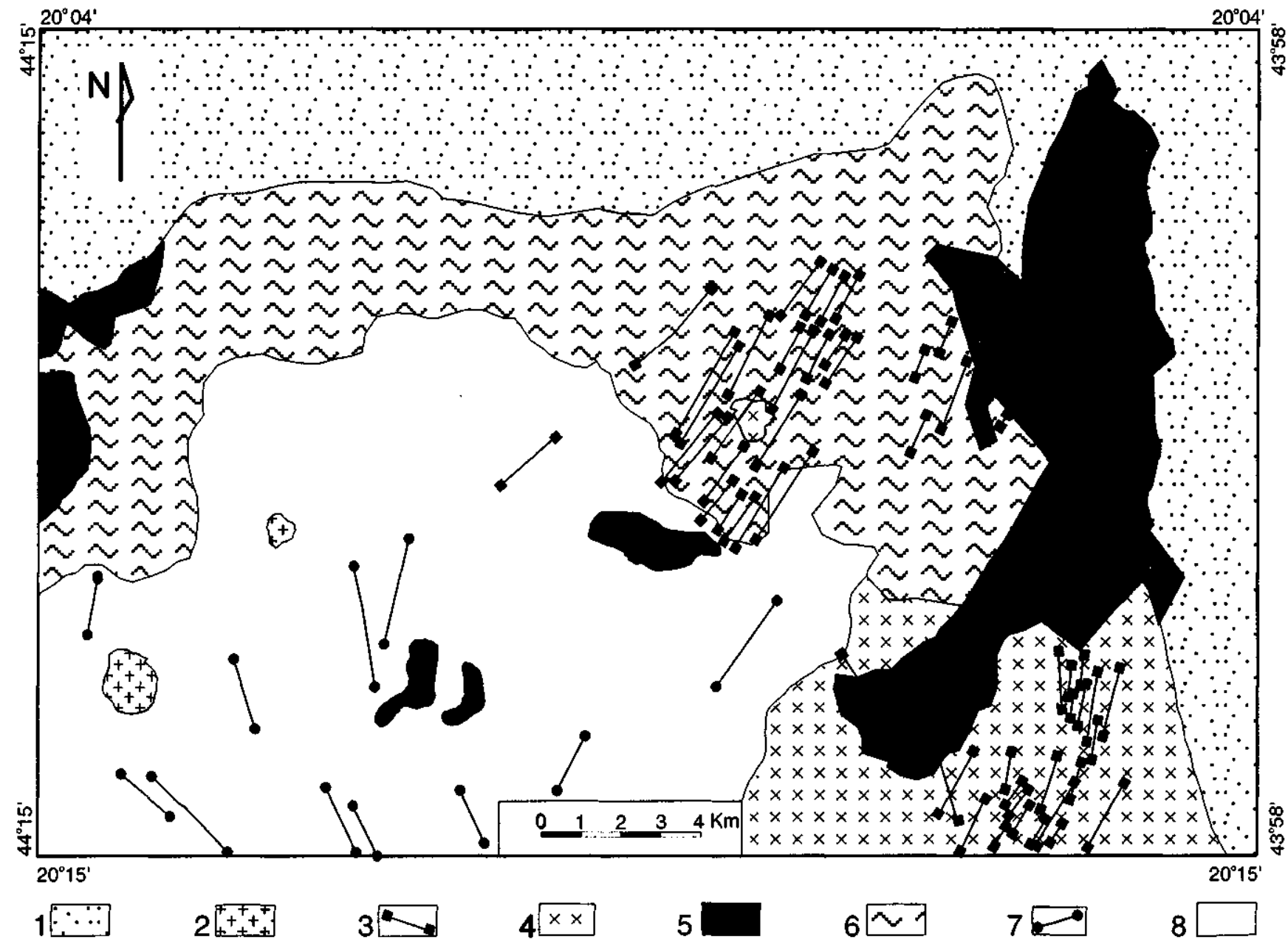

Figure 2 - Geological map of the Northern Bonfim Metamorphic Complex (after Carneiro 1992, Carneiro et al. 1997,1998). Keys: 1 - Minas Supergroup; 2 - Brumadinho Granite; 3 -Candeias Amphibolite; 4 - Samambaia Tonalite; 5 - Rio das Velhas Greenstone Belt; 6 - Souza Noschese Gneiss; 7 -Paraopeba Amphibolite; 8 - Alberto Flores Gneiss.

Figura 2 - Mapa geologico da porção norte do Complexo Metam6rfico Bonfim (segundo Carneiro 1992, Carneiro et al. 1997, 1998). Legendas: 1 - Supergrupo Minas; 2 - Granite Brumadinho; 3 - Anfibolito Candeias; 4- Tonalito Samambaia; 5 - Greenstone Belt Rio das Velhas; 6 - Gnaisse Souza Noschese; 7 - Anfibolito Paraopeba; 8 - Gnaisse Alberto Flores.

zircon, and titanite. The plagioclase is usually saussuritized and biotite contains secondary chlorite and epidote.

The Paraopeba Amphibolite (PA) crops out as disrupted and boudinaged dikes within the AFG. This amphibolite has a granonematoblastic texture characterized by alternating mafic bands of brown hornblende and felsic bands of plagioclase and minor quartz. Opaque minerals are surrounded by anhedral titanite, plagioclase crystals are generally saussuritized, and biotite commonly replaces hornblende.

The Souza Noschese Gneiss (SNG), who is intrusive into the AFG, displays no banding but exhibits everywhere a weak mylonitic foliation. In thin section, the SNG rocks have a granoblastic texture, and consist mainly of microcline with subordinate plagioclase and quartz. Biotite and secondary muscovite are varietal minerals. Apatite, zircon, titanite, and opaque minerals are the common accessory minerals.

The Samambaia Tonalite (ST) intrudes both the AFG and SNG. The ST is a gray granitoid rock with hypidiomorphic texture, containing euhedral to sub-euhedral plagioclase with minor quartz and subordinate microcline. Brown hornblende and biotite are common varietal minerals. Zircon, apatite, titanite, and opaque grains are the accessory minerals.

The Candeias Amphibolite (CA) occurs as dikes cutting the ST, and less commonly also the SNG and AFG. This amphibolite has a poikiloblastic texture and .contains hornblende with abundant inclusions of quartz, as well as minor plagioclase and quartz. Titanite, apatite, and opaque minerals are the accessory minerals.

The Brumadinho Granite (BG) intrudes all the other units of the NBMC. The best exposure of the BG occurs in a quarry located near the village of Brumadinho (Fig. 2). In this quarry, a granite dyke cuts across the NS gneissic banding of the AFG (Fig. 3). Normally, BG dikes are less than one meter wide and are fine-grained, gray-colored rocks with granite composition. In thin section the rock has a hypidiomorphic texture, and is made up of microcline and minor plagioclase and quartz. Biotite is rare and normally chloritized. Apatite, zircon, titanite, and opaque minerals are the accessory minerals.

ANALYTICAL METHODS Whole rock geochemistry Whole rock samples were analyzed at the GEOSOL Laboratory, Belo Horizonte, Brazil. Major elements (Al, Ca, (totai)Fe, $\mathrm{Si}, \mathrm{Mg}, \mathrm{P}, \mathrm{Cr}, \mathrm{Ti}$ ) and minor elements (Ba, Cl, Cs, S, $\mathrm{Nb}, \mathrm{Rb}, \mathrm{Sr}, \mathrm{Y}, \mathrm{Zr}$ ) were analyzed by XRF with an accuracy of about $1 \%$ for major elements and $5 \%$ for minor elements. Atomic absorption was carried out for $\mathrm{K}, \mathrm{Mg}, \mathrm{Mn}, \mathrm{Na}$, and $\mathrm{Pb}$ with an accuracy of $\pm 5 \%$. Optic spectrography was used to determine levels of $\mathrm{Zn}, \mathrm{Cu}, \mathrm{Co}, \mathrm{Sc}, \mathrm{Ni}$, and $\mathrm{V}$ with errors less 
than $5 \%$. Trace elements, including REE, were determined on ICP-MS (VG plasmaquad) with analytical precision for most elements better than $5 \%$.

U-Pb Geochronology The U-Pb dates on zircons and titanite were done at Geotop/UQAM/ Montreal, Canada. Crystal selection, chemistry, mass spectrometry, and data treatment followed previously reported procedures (Krogh 1973, 1982a, b, Davis 1982, Corfu \& Stott 1986, Machado et al. 1989, 1991). Maximum total blanks for zircon analyses at the Geotop are $15 \mathrm{pg}$. for $\mathrm{Pb}$ and $2 \mathrm{pg}$. for $\mathrm{U}$. For titanite analyses these values are 25 and $5 \mathrm{pg}$., respectively. The isotopic composition of initial common $\mathrm{Pb}$ was calculated according the two-stage model of Stacey \& Kramers (1975). The decay constants used were those recommended by the International Union of Geological Sciences (Steiger \& Jäeger 1978).

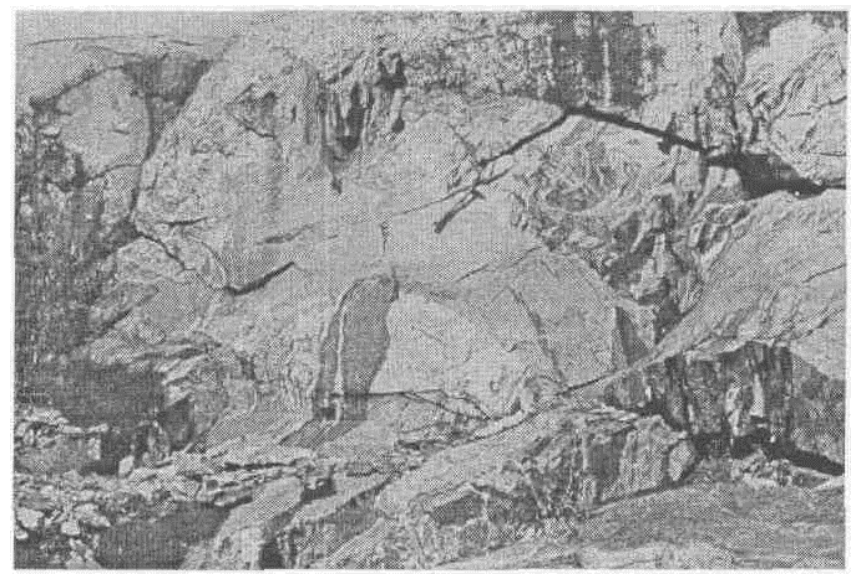

Figure 3 - Alberto Flores banded Gneiss truncated by the Brumadinho Granite dike.

Figura 3 - Gnaisse Alberto Flores truncado por um dique do Granite Brumadinho.
Sm-Nd, Rb-Sr and K-Ar dates The $\mathrm{Sm}-\mathrm{Nd}, \mathrm{Rb}-\mathrm{Sr}$, and $\mathrm{K}-\mathrm{Ar}$ dates were carried out at the Geochronological Research Center - CPGeo of University of Sao Paulo, Brazil.

All the isotopic ratios were measured using a VG-354 mass spectrometer of CPGeo. A two-column technique was used for the Sm-Nd analyses. First an ion exchange resin was employed for separation of the REE, and then a HDEHPcoated Teflon powder column for the separation of Sm and $\mathrm{Nd}$ elements. Details for the analytical procedures are reported inSatoera/. (1995).

The laboratory blanks for $\mathrm{Nd}$ and $\mathrm{Sm}$ elements yield maximum values of 70 and $30 \mathrm{pg}$., respectively. The average measured ${ }^{143} \mathrm{Nd} /{ }^{144} \mathrm{Nd}$ values of the La Jolla Nd and BCR-1 standards are $0.511849 \pm 0.000025$ and $0.512662 \pm 0.000027$ respectively, with errors at $1 \varepsilon$ level.

TDM model ages (see Teixeira et al. 1996) were recalculated using DePaolo (1981) model parameters (see Table 4): $\mathrm{a}=0.25 ; \mathrm{b}=-3 ; \mathrm{c}=8.5$ and ${ }^{146} \mathrm{Nd} /{ }^{144} \mathrm{Nd}=0.7219$ to normalize the isotopic ratios $\left[{ }^{143} \mathrm{Nd} /{ }^{144} \mathrm{Nd}\right.$ (Chur)o $=0.512638$ and ${ }^{147} \mathrm{Sm} /{ }^{144} \mathrm{Nd}$ (Chur) $\left.)_{0}=0.1967\right]$. The $\varepsilon_{\mathrm{Nd}}$ values were calculated using the simplified equation $\varepsilon_{\mathrm{Nd}}(\mathrm{T})=\varepsilon_{\mathrm{Nd}}(0)-$ $\mathrm{Qf}_{\mathrm{Sm}} / \mathrm{Nd}$, with the CHUR (0) values above and $\mathrm{Q}_{\mathrm{Nd}}=25.09$ (cf. Rollinson 1993). The age calculations for the Rb-Sr analyses used decay constants recommended by Steiger \& Jaeger (1978).

The $\mathrm{Rb}$ and $\mathrm{Sr}$ determinations on unspiked samples were measured by X-ray Fluorescence with precision of approximately $2 \%$. Isotope dilution analyses were earned out on samples with $\mathrm{Rb}$ and $\mathrm{Sr}$ contents lower than $50 \mathrm{ppm}$ and higher than $500 \mathrm{ppm}$. The K-Ar analyses were carried out on biotite and hornblende. Age calculations and experimental work followed procedures reported in Amaral et al. (1966). Isotopes analyses were measured in a Nuclide (Reynolds type) mass spectrometer of the CPGeo.

RESULTS AND DISCUSSION Geochemistry of the felsic units Table 2 presents major and trace element data for samples of NBMC felsic rocks. The chemical data, were plotted in an AFM diagram (Fig. 4A), defining a calcalkaline trend. The protolith types of the AFG and the SNG can be better understood using the classification scheme

Table 1 - Chrono-Lithostratigraphy of the Northern Bonfim Metamorphic Complex modified from Carneiro (1992), Carneiro et al. (1997, 1998).

Tabela 1 - Crono-litoestratigrafia da porcao norte do Complexo Metamorfico Bonfim, modificado de Carneiro (5992), Carneiro et al. (1997, 1998).

\begin{tabular}{|c|c|c|c|c|}
\hline \multirow{2}{*}{$\begin{array}{l}\text { Lithostratigraphic Units } \\
\text { of NBMC }\end{array}$} & \multirow[t]{2}{*}{ Major Geological Features } & \multicolumn{3}{|c|}{ Ages (Ma) } \\
\hline & & $\mathrm{U}-\mathrm{Pb}^{1}$ & $\mathrm{Rb}-\mathrm{Sr}^{2}(\mathrm{WR})^{3}$ & $\mathrm{~K}-\mathrm{Ar}^{2}$ \\
\hline $\begin{array}{l}\text { Brumadinho Granite } \\
\text { (BG) }\end{array}$ & $\begin{array}{l}\text { Small intrusive bodies and dikes cutting the } \\
\text { gneissic banding of the Alberto Flores Gneiss }\end{array}$ & $\begin{array}{c}2703+24 /-20 \\
\text { (Zircon) }\end{array}$ & $\begin{array}{c}982 \pm 91 \\
\mathrm{R}_{0}=0.741 \pm 0.002 \\
\mathrm{MSWD}=10.30\end{array}$ & $\begin{array}{l}1090-700 \\
\text { (Biotite) }\end{array}$ \\
\hline $\begin{array}{l}\text { Candeias Amphibolite } \\
\text { (CA) }\end{array}$ & $\begin{array}{l}\text { Mafic dikes with rare plagioclase } \\
\text { blastophenocrysts and poikiloblastic hornblende, } \\
\text { mainly within the Samambaia Tonalite }\end{array}$ & - & - & $\begin{array}{c}1710 \\
\text { (Hornblende) }\end{array}$ \\
\hline $\begin{array}{l}\text { Samambaia Tonalite } \\
\text { (ST) }\end{array}$ & Gray rocks with igneous texture, locally sheared & $\begin{array}{l}2778+3 /-2 \\
\text { (Zircon and } \\
\text { Titanite) }\end{array}$ & $\begin{array}{c}1188 \pm 46 \\
R_{0}=0.713 \pm 0.0005 \\
M S W D=24.93\end{array}$ & $\begin{array}{l}1120-720 \\
\text { (Biotite) }\end{array}$ \\
\hline $\begin{array}{l}\text { Souza Noschese Gneiss } \\
\text { (SNG) }\end{array}$ & Sheared gray granitic ortho-gneiss (?) & - & $\begin{array}{c}1295 \pm 80 \\
R_{0}=1.006 \pm 0.017 \\
\text { MSWD }=7.94\end{array}$ & - \\
\hline $\begin{array}{l}\text { Paraopeba Amphibolite } \\
\text { (PA) }\end{array}$ & $\begin{array}{l}\text { Boudinaded and disrupted mafic dikes with } \\
\text { granonematoblastic texture within the Alberto } \\
\text { Flores Gneiss }\end{array}$ & - & 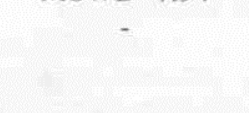 & $\begin{array}{r}2160-1930 \\
\text { (Hornblende) }\end{array}$ \\
\hline $\begin{array}{l}\text { Alberto Flores Gneiss } \\
\text { (AFG) }\end{array}$ & Trondhjemitic/granitic banded gray gneiss & $\begin{array}{l}2772 \pm 6^{4} \\
2920^{5} \\
\text { (Zircon) }\end{array}$ & $\begin{array}{c}2219 \pm 80 \\
R_{0}=0.707 \pm 0.001 \\
\text { MSWD }=2.13\end{array}$ & $\begin{array}{c}540 \\
\text { (Biotite) }\end{array}$ \\
\hline
\end{tabular}

${ }^{1}$ Machado \& Carneiro (1992); ${ }^{2}$ Carneiro et al. (1998); ${ }^{3}$ Isochron; ${ }^{4}$ Zircon overgrowth; ${ }^{5}$ Zircon core 
(O'Connor 1965) of Figure 4B. The majority of AFG samples fall within the trondhjemitic field, while the SNG samples, of strictly granitic composition, plot in the same field as the BG granitic samples in Figure 4B. The ST samples, obviously, plot in the tonalite field.

The mean chondrite-normalized REE distribution patterns of the NBMC felsic units are shown in Figure 5A.

All REE-patterns are sub-parallel and quite similar in overall shape, but they have different REE concentration levels.

The ST has the highest concentration of REE, while the BG the lowest. The REE patterns of the two gneissic units fall between the $\mathbf{S T}$ and the BG granitoid patterns. Each unit has its own fractionation with respect to the light-REE enrichment. The degree of fractionation $(\mathrm{La} / \mathrm{Yb})_{\mathrm{N}}$, varies from 40 (BG) to 8 (SNG). $(\mathrm{La} / \mathrm{Yb})_{\mathrm{N}}$ ratios of 20 are present in the AFG and ST. The REE envelope pattern of the felsic units of the NBMC is compatible with the high $\mathrm{Al}_{2} \mathrm{O}_{3}$ REE envelope pattern of most NeoArchaean trondhjemites (Condie 1981).
Except in the BG, which has a HREE depletion with a valley in the $\mathrm{Er}-\mathrm{Yb}$ interval, all felsic rods have an average patterns with a significant negative Eu-anomaly. The high (LaN/Ybisr) of 20 in the AFG implies that the protolith of this gneiss results from partial melting of either quartz eclogite, garnet amphibolite or LREE-enriched amphibolite source, as recognized in worldwide NeoArchaean granite-greenstone terranes by Condie (1989), Martin (1987), McGregor et al. (1985), Rapp et al (1991), Sarkar et al. (1993).

Figure 5B shows that all the NBMC felsic units have a similar pattern of ORG-normalized incompatible element abundance. The SNG shows a small positive Sm anomaly and an expected high negative Eu anomaly (Fig. 5A). It is worth mention the high concentrations of the elements of the left side of the spectrum and the distinctive positive $\mathrm{Rb}$ anomalies resulting from post-crystallization alteration and Proterozoic low grade metamorphism and consequent disturbance of the Rb-Sr system (Carneiro 1992, Carneiro et al 1997, 1998).
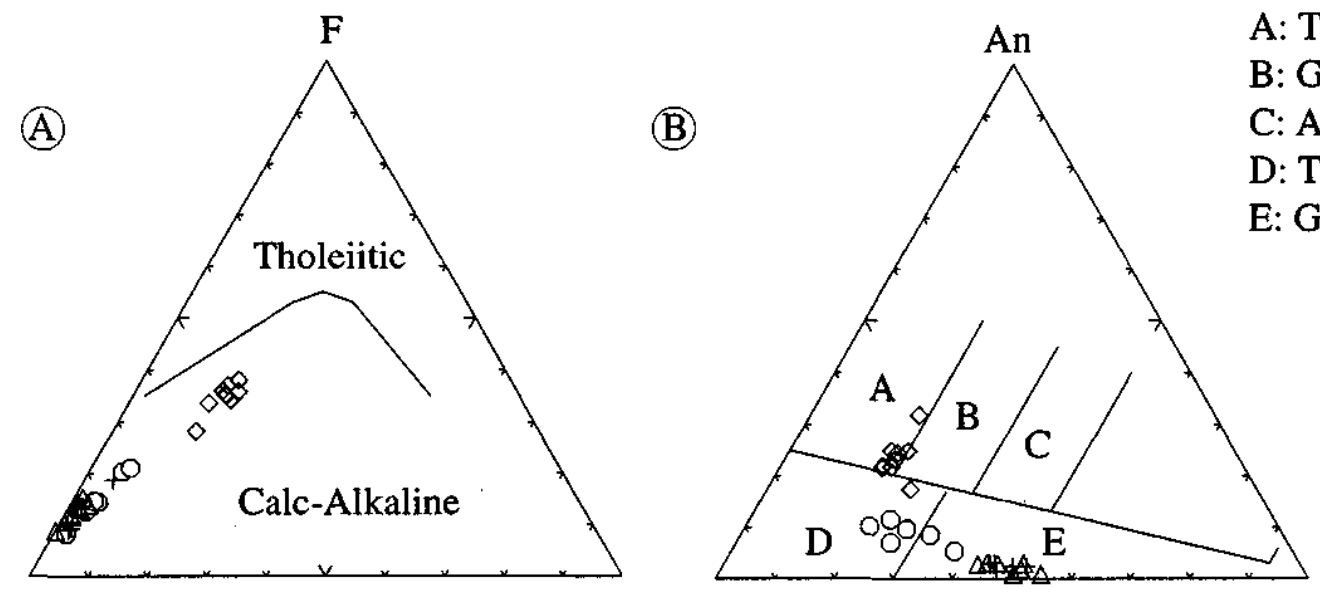

A: Tonalite

B: Granodiorite

C: Adamellite

D: Trondhjemite

E: Granite

A

$\mathrm{M}$

$\mathrm{Ab}$

Or

\section{$\bigcirc$ Alberto Flores Gneiss $\quad \triangle$ Souza Nochese Gneiss $\quad \diamond$ Samambaia Tonalite $\quad$ + Brumadinho Granite}

Figure 4 - Felsic suites of the Northern Bonfim Metamorphic Complex. (A) - AFM diagram; Fields from Irvine \& Baragar (1971). (B) - Plot of normative anorthite (An), albite (Ab) and orthoclase (Or); fields from O'Connor (1965).

Figure 4 - Suites félsicas da porção norte do Complexo Metamdrfico Bonfim. (A) - Diagrama AFM de Irvine \& Baragar (1971) das suítes félsicas. (B) - Diagrama anortita (An), albita (Ab) e ortoclasio (Or) normativos (O'Connor 1965).

(A)

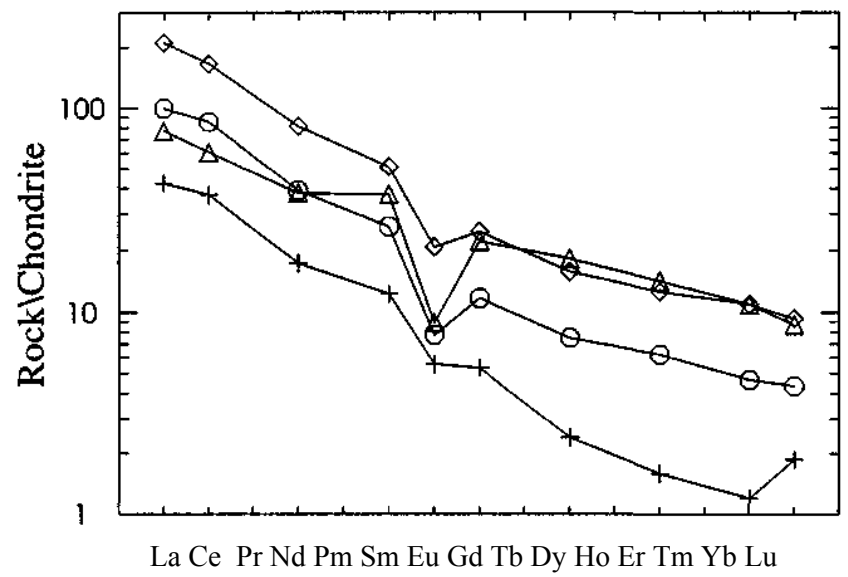

o Alberto Flores Gneiss A Souza Nochese Gneiss
(B)

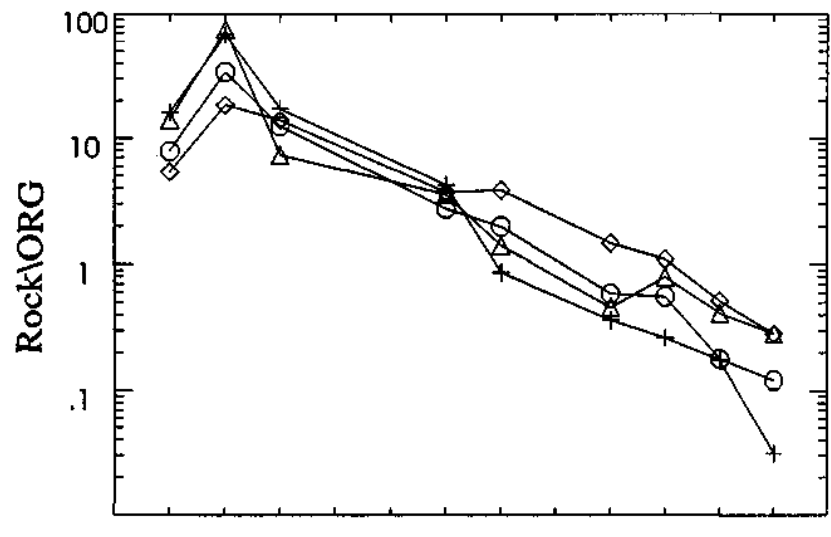

$\mathrm{K}_{2} \mathrm{O} \mathrm{Rb} \mathrm{Ba} \mathrm{Th} \mathrm{Ta} \mathrm{Nb}$ Ce Hf $\mathrm{Zr} \mathrm{Sm} \mathrm{Y} \mathrm{Yb}$

o Samambaia Tonalite + Brumadinho Granite

Figure 5 - Felsic suites of the Northern Bonfim Metamorphic Complex. (A) - Chondrite-normalized REE patterns; normalizing values after Massuda et al. (1973. (B) -ORG-normalized spidergram; normalizing values after Pearce et al. (1984).

Figure 5 - Suites felsicas da porção norte do Complexo Metamorfico Bonfim. (A) - Padroes de Terras Raras normalizados ao condrito; valores de normalizacao segundo Massuda et al. (1973). (B) - Spidergram de valores normalizados ao ORG; valores de normaliza9ao segundo Pearce et al. (1984). 
Table 2 - Major (wt \%), trace (ppm), and rare earth (ppb) elements analyses of representative samples of the Alberto Flores and Souza Noschese Gneisses, Samambaia Tonalite, and Brumadinho Granite.

Tabela 2 - Elementos maiores (\% em peso), traço (ppm), e Terras Raras (ppb) de amostras representativas dos gnaisses Alberto Flores e Souza Noschese, Tonalito Samambaia e Granito Brumadinho.

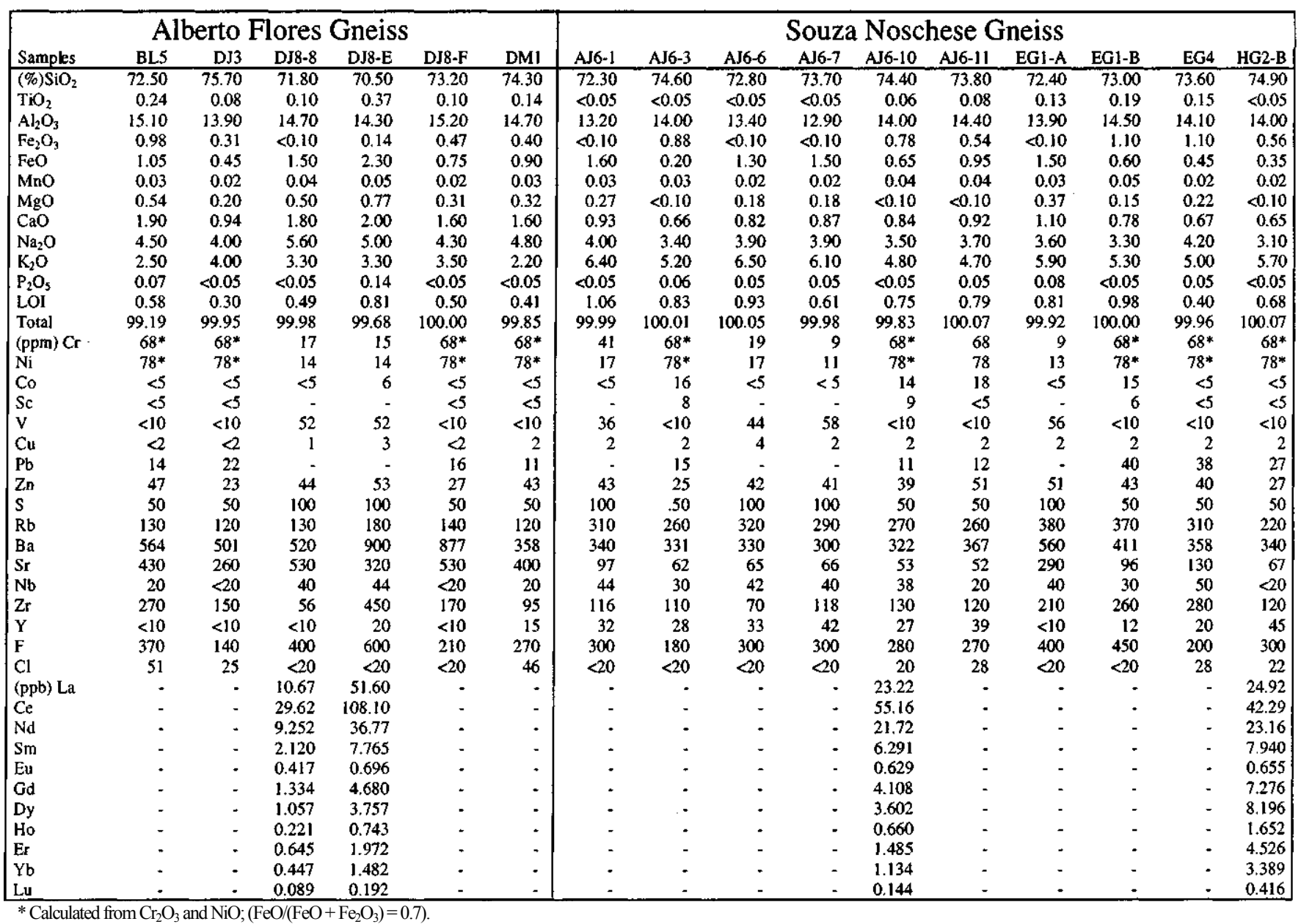

Geochemistry of the mafic units Major and trace element data of the NBMC mafic units are given in Table 3. The chemical data of the two mafic units, plotted on AFM diagram (Fig. 6A), spread predominantly within the tholeiitic field.

In order to investigate the protolith chemistry of these samples the classification of Winchester \& Floyd (1977) is presented in Figure 6B. According to the figure, the PA samples plot in the sub-alkaline basalt field, and the CA samples in the andesite/basalt, sub-alkaline basalt and alkalibasalt fields. The REE patterns of the two mafic units are similar and have the same $\left(\mathrm{La}_{\mathrm{N}} / \mathrm{Yb}_{\mathrm{N}}\right)=2$ (Fig. 7A)

If NBMC mafic units average composition are compared to mid-ocean ridge basalts (MORE) both are markedly richer in $\mathrm{K}, \mathrm{Rb}, \mathrm{Ba}$, and $\mathrm{Nb}$, as shown by the hump-shaped patterns in the left side of the spidergram (Fig. 7B) similar to the modern withinplate basalt (Carneiro et al. 1998).

\section{U-Pb, Sm-Nd, Rb-Sr, and K-Ar Geochronology}

The U-Pb geochronology of the NBMC units has been already reported in Carneiro (1992), and Machado \& Carneiro (1992). Table 1 summarizes the U-Pb, $\mathrm{Rb}-\mathrm{Sr}$ and $\mathrm{K}-\mathrm{Ar}$ data available for the NBMC.

The $\mathrm{U}-\mathrm{Pb}$ age of the AFG was obtained in single zircon crystals (core and overgrowth), interpreted in a Concordia plot. The Discordia between these two analyses reaches the Concordia at $3280 \mathrm{Ma}$. The ${ }^{207} \mathrm{~Pb}-{ }^{20} \mathrm{~Pb}$ age of the core, which plots slightly discordant to the Concordia (1.1\%), yielded an age of $2920 \mathrm{Ma}$. The zircon overgrowth defined a concordant age of $2772 \pm 6 \mathrm{Ma}$. A similar $2920 \mathrm{Ma}{ }^{207} \mathrm{Rb}-{ }^{206} \mathrm{~Pb}$ zircon age was reported for the Belo Horizonte trondhjemitic gneisse (BHG; Noce 1995) cropping out north of the NBMC.

The SNG could not be dated by the U-Pb method since its zircons are strongly altered (Carneiro 1992). However, the ST, intrusive in the SNG, yielded a U-Pb age of $2778+3 /-2$ Ma. (Table 1), obtained from various fractions of zircon and titanite (Carneiro 1992, Machado \& Carneiro 1992). Titanite of ST yielded a U-Pb age of ca. $2770 \mathrm{Ma}$, indicating that, if a metamorphic episode post-dating the Archaean evolution overprinted the NBMC, the P-T conditions are below the amphibolite facies (Machado \& Carneiro 1992).

The U-Pb age of the BG (Table 1) is $2703+24 /-20 \mathrm{Ma}$ according to the upper intercept of three zircon fractions in a Discordia plot (Carneiro 1992, Machado \& Carneiro 1992).

$\mathrm{U}-\mathrm{Pb}$ zircon ages, comparable to those of the AFG and the ST, have been reported for a granitoid from the Caete Complex (Machado et al. 1992), located to the northeast of the NBMC (2776+77-6 Ma) and two felsic volcanic rocks from the RVGB $(2772 \pm 6 \mathrm{Ma}$ and $2776+237-10 \mathrm{Ma})$. Older ${ }^{207} \mathrm{pb}-{ }^{206} \mathrm{pb}$ (icpMS) model ages up to 3,200 Ma are reported for detrital zircons from quartzites of the QF (Machado et al. 1993, Machado etal. 1996). Sm-Nd $\mathrm{T}_{\mathrm{DM}}$ crust formation ages and $\mathrm{U}-\mathrm{Pb}$ zircon ages up to $3200 \mathrm{Ma}$ (Teixeira et al. 1998) 
Table 2 - Continuation

Table 2 - Continuação

\begin{tabular}{|c|c|c|c|c|c|c|c|c|c|c|c|c|c|c|c|c|}
\hline \multirow[b]{2}{*}{ Samples } & \multicolumn{6}{|c|}{ Samambaia Tonalite** } & \multirow[b]{2}{*}{ MNJO-H } & \multirow[b]{2}{*}{ MN $10-\mathrm{J}$} & \multirow[b]{2}{*}{ NKS } & \multicolumn{7}{|c|}{ Brumadinho Granite } \\
\hline & ML8-J & ML13-A & MM6-A & MN10-A & MN $10-E$ & MNJO-F & & & & BL4-3 & DJI & DJ8-C & 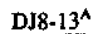 & DJ8-13B & DJ8-14 & IO1-D \\
\hline$(\%) \mathrm{SiO}_{2}$ & 68.00 & 64,00 & 63.10 & 64.10 & 65.80 & 64.40 & 64.60 & $\overline{64.80}$ & 67.20 & 68.50 & 69.20 & 71.70 & $70.90^{\prime \prime}$ & 71.80 & 71.70 & 71.80 \\
\hline $\mathrm{TH}_{2}$ & 0.46 & 0.81 & 0.76 & 0.71 & 0.68 & 0.68 & 0.73 & 0.69 & 0.56 & 0.56 & 0.54 & 0.08 & 0.12 & 0.08 & 0.10 & 0.08 \\
\hline $\mathrm{Al}_{2} \mathrm{O}_{3}$ & 14.20 & 16.10 & 17.30 & 15.30 & 14.90 & 15.10 & 14.70 & 15.30 & 15.40 & 14.30 & 14.10 & 13.80 & 14.50 & 14.30 & 14.10 & 13.20 \\
\hline $\mathrm{Fe}_{2} \mathrm{O}_{3}$ & 0.58 & 2.00 & 2.30 & 0.98 & 0.54 & 3.10 & 0.50 & 0.64 & 2.60 & 0.58 & 0.58 & 0.12 & $<0.10$ & $<0.10$ & 0.10 & $<0.10$ \\
\hline $\mathrm{FeO}$ & 2.90 & 2.90 & 2.60 & 3.80 & 4.10 & 1.90 & 4.50 & 4.10 & 1.40 & 2.00 & 2.00 & 1.00 & 1.50 & 1.30 & 1.00 & 1.30 \\
\hline MnO & 0.06 & 0.07 & 0.06 & 0.06 & 0.06 & 0.07 & 0.07 & 0.07 & 0.07 & 0.02 & 0.03 & 0.03 & 0.04 & 0,03 & 0.03 & 0.02 \\
\hline $\mathrm{MgO}$ & 1.70 & 1.90 & 2,00 & 2.30 & 2.00 & 2.10 & 2.40 & 1.90 & 1.50 & 0.83 & 0.67 & 0.27 & 0.28 & 0.28 & 0.30 & 0.28 \\
\hline $\mathrm{CaO}$ & 13.60 & 4.20 & 4.80 & 4.70 & 4.30 & 4.40 & 4.40 & 4.50 & 3.80 & 1.40 & 1.30 & 1.10 & 1.20 & 1.10 & 1.20 & 0.66 \\
\hline $\mathrm{K}_{2} \mathrm{O}$ & 2.70 & 1.90 & 2.00 & 2.00 & 2.10 & 2.00 & 2.10 & 2.10 & 2.10 & 6.60 & 6.20 & 6.20 & 5.90 & 5.70 & 6.00 & 8.00 \\
\hline $\mathrm{P}_{2} \mathrm{O}_{5}$ & 0.14 & 0.21 & 0.21 & 0.21 & 0.19 & 0.21 & 0.22 & 0.22 & 0.16 & 0.14 & 0.16 & $<0.05$ & $<0.05$ & $<0.05$ & $<0.05$ & $<0.05$ \\
\hline LOI & 1.07 & 1.55 & 1.17 & 0.80 & 0.92 & 1.21 & 1.18 & 1.02 & 1.29 & 0.95 & 0.93 & 0.92 & 0.88 & 0.77 & 0.87 & 0.93 \\
\hline Total & 99.71 & 99.84 & 99.90 & 99.66 & 99.89 & 99.77 & 99.80 & 99.64 & 99.88 & 99.88 & 99.81 & 100.07 & 99.87 & 99.91 & 99.85 & 100.02 \\
\hline$(\mathrm{ppm}) \mathrm{Cr}$ & 18 & $68^{*}$ & $68 *$ & 32 & 28 & 26 & 32 & 30 & $68^{*}$ & 19 & 13 & 9 & 13 & 16 & 12 & 9 \\
\hline $\mathrm{Ni}$ & 22 & $78^{*}$ & $78^{*}$ & 30 & 28 & 27 & 30 & 26 & $78^{*}$ & 16 & 13 & 14 & 13 & 11 & 11 & 11 \\
\hline $\mathrm{Co}_{0}$ & 10 & 24 & 26 & 14 & 13 & 13 & 14 & 13 & 24 & 5 & 6 & $<5$ & $<5$ & 5 & $<5$ & $<$ \\
\hline $\mathrm{Sc}$ & - & 10 & 12 & - & - & - & - & - & 9 & - & - & . & - & - & - & - \\
\hline$v$ & 82 & 72 & 67 & 100 & 96 & 108 & 100 & 78 & 56 & 84 & 50 & 46 & 76 & 46 & 36 & 68 \\
\hline $\mathrm{Cu}$ & 17 & 8 & 15 & 16 & 17 & 15 & 17 & 13 & 25 & 6 & 11 & 6 & 5 & 2 & 7 & 1 \\
\hline$z_{n}$ & 66 & 86 & 80 & 75 & 76 & 70 & 76 & 72 & 71 & 61 & 76 & 32 & 34 & 30 & 30 & 19 \\
\hline $\mathrm{s}$ & 110 & 50 & so & 130 & 130 & 130 & 140 & 130 & 50 & 120 & 100 & 130 & 130 & 100 & 100 & 100 \\
\hline $\mathrm{Rb}$ & 100 & 56 & 92 & 63 & 68 & 69 & 66 & 67 & 84 & 340 & 310 & 210 & 230 & 230 & 210 & 380 \\
\hline $\mathbf{B a}$ & 710 & 599 & 779 & 730 & 720 & 750 & 790 & 700 & 402 & 1110 & 1120 & 830 & 840 & 840 & 720 & 530 \\
\hline$\$ \mathbf{r}$ & 340 & 290 & 340 & 380 & 360 & 370 & 330 & 360 & 320 & 230 & 260 & 280 & 320 & 360 & 340 & 85 \\
\hline Nb & 42 & 20 & 30 & 42 & 42 & 40 & 42 & 50 & 25 & 56 & 44 & 48 & 44 & 30 & 40 & 30 \\
\hline $\mathrm{Zr}$ & 380 & 400 & 470 & 480 & 620 & 520 & 620 & 600 & $3 \overline{40}$ & 760 & 780 & 136 & 118 & 112 & 116 & 90 \\
\hline $\mathrm{Y}$ & 30 & 36 & 42 & 38 & 33 & 35 & 37 & 37 & 36 & 16 & 15 & $<10$ & $<10$ & $<10$ & $<10$ & 15 \\
\hline F & 700 & 590 & 540 & 900 & 900 & 700 & 1000 & 800 & 850 & 300 & 700 & 200 & 200 & 100 & 100 & 200 \\
\hline $\mathrm{Cl}$ & $<20$ & 39 & 73 & 110 & 110 & 120 & 130 & 130 & 20 & 180 & 66 & $<20$ & $<20$ & $<20$ & $<20$ & $<20$ \\
\hline (ppb) $\mathbf{L a}$ & 52.06 & - & - & - & 79.78 & - & - & - & -1 & - & - & 13.07 & - & - & 13.40 & - \\
\hline $\mathrm{Ce}$ & 113.70 & - & $=$ & - & 152,60 & . & - & . &. & - &. & 29.04 & - & $=$ & 30.71 & - \\
\hline$N d$ & 37.21 & . & - & . & 58.63 & . & . & - & - & . & ـ & 10.20 & . & - & 10.31 & . \\
\hline$S \mathrm{~m}$ & 7.466 & . & - & - & 12.01 & $=$ & - & $=$ &. & - & $=$ & 2.20 & - & . & 2.478 & - \\
\hline Eu & 1.169 & - & $=$ & $=$ & 1.787 & $=$ & - & . & $=1$ & - & $=$ & 0.368 & - & $=$ & 0.424 & - \\
\hline $\mathrm{Gd}$ & 4.806 & . & - & . & 7.809 & - & . & - &. & - & - & 1.330 & - & - & 1.414 & - \\
\hline Dy & 3.671 & - & - & - & 6.442 & - & - & - & $\cdot$ & - & - & 0.710 & - & - & 0.844 & - \\
\hline Ho & 0.745 & - & - & . & 1.259 & - & - & . & -1 & - & - & 0.122 & . & - & 0.160 & . \\
\hline Er & 2.066 & $=$ & - & . & 3.248 & $=$ & $=$ & - & - & - & - & 0.294 & - & - & 0.389 & . \\
\hline $\mathrm{Yb}$ & 1.826 & - & - & - & 2.671 & - & - & - & -1 & - & - & 0.208 & - & - & 0.296 & - \\
\hline
\end{tabular}

* Calculated from $\mathrm{Cr}_{2} \mathrm{O}_{3}$ and $\mathrm{NiO} ;\left(\mathrm{FeO} /\left(\mathrm{FeO}+\mathrm{Fe}_{2} \mathrm{O}_{3}\right)=0.7\right) ; *$ Data from Carneiro el al. (1997).

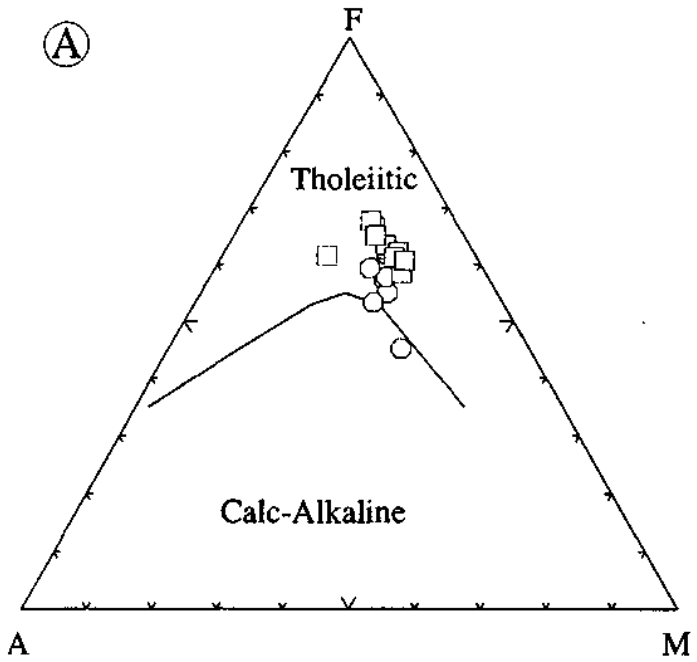

Paraopeba Amphibolite
(B)

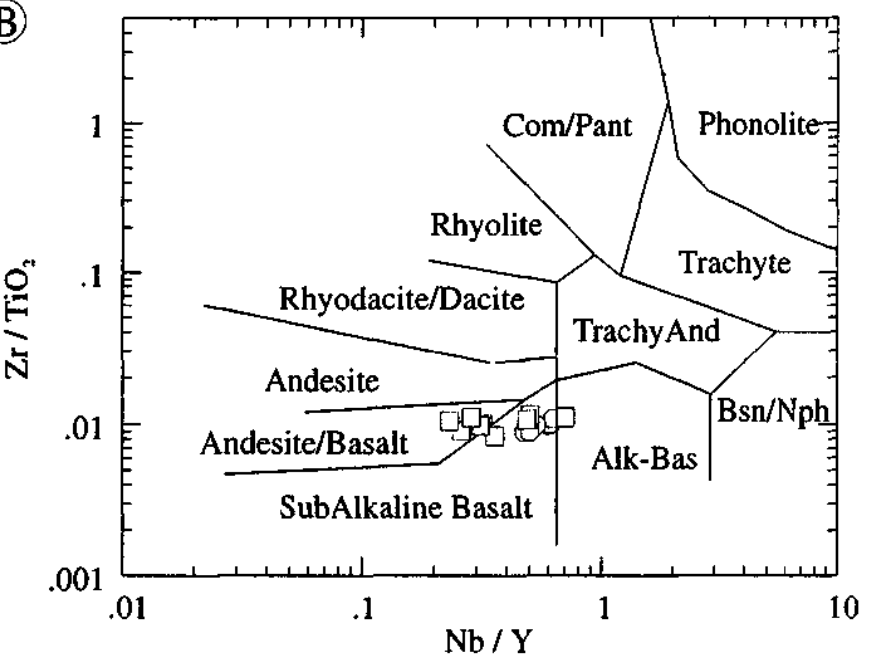

Candeias Amphibolite

Figure 6 - Mafic suites of the Northern Bonfim Metamorphic Complex (A) - Irvine \& Baragar (1971) AFM diagram showing a tholeiitic chemistry of the mafic. (B) - Composition plotted in the discriminant diagram for volcanic rock types based on $\mathrm{Zr} / \mathrm{Ti} \mathrm{O}_{2}$ and $\mathrm{Nb} / Y$ log ratios; fields from Winchester \& Floyd (1977).

Figure 6a - Suítes máficas da porção norte do Complexo Metamórfico Bonfim. (A) Diagrama AFM de Irving \& Baragar (1971) mostrando a química toleíltica das suítes máficas. (B) - Composição de amostras das suítes no diagrama discriminante de rochas vulcânicas (Winchester \& Floyd 1977). 
(A)

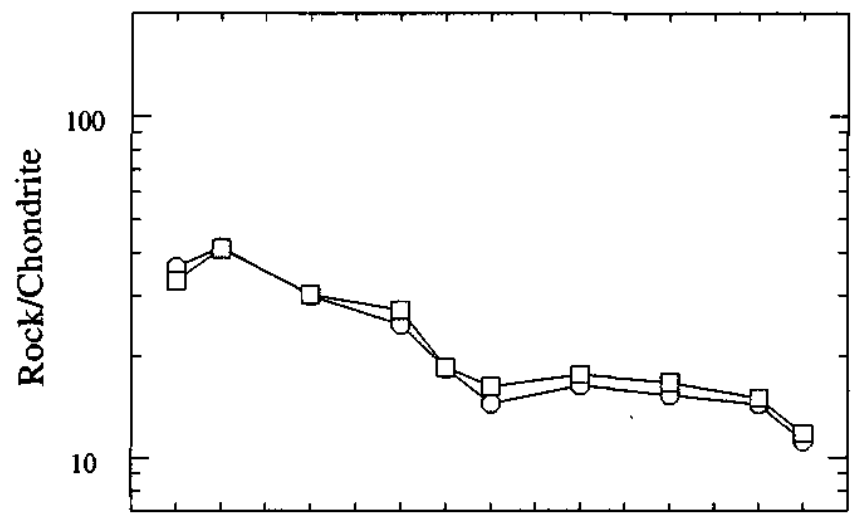

La Ce Pr Nd Pm Sm Eu Gd Tb Dy Ho Er Tm Yb Lu

o Paraopeba Amphibolite
(B)

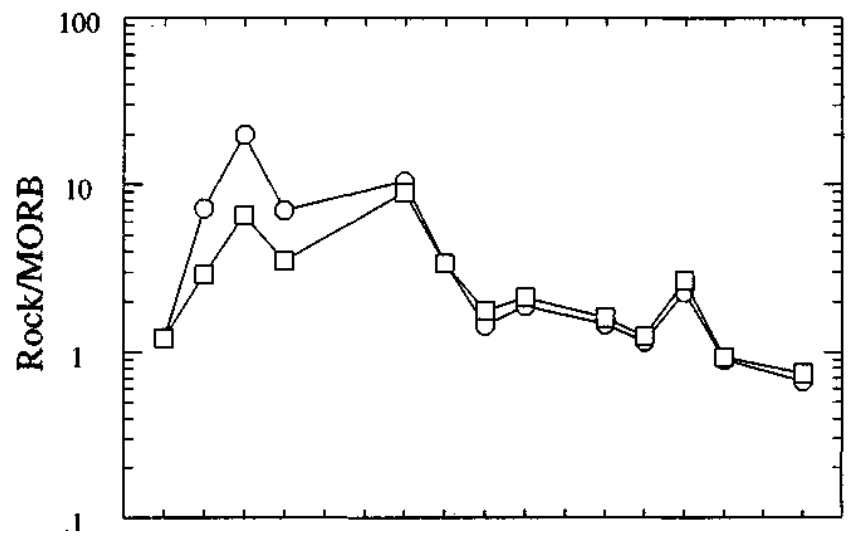

$\mathrm{Sr} \mathrm{K}_{2} \mathrm{O}$ Rb Ba Th $\mathrm{Ta} \mathrm{Nb} \mathrm{Ce} \mathrm{P}_{2} \mathrm{O}_{5} \mathrm{Zr} \mathrm{Hf} \mathrm{Sm} \mathrm{TiO} 2, \mathrm{Y}$ Yb Sc Cr

n Candeias Amphibolite

Figure 7A - Chondrite-normalized REE patterns for the mafic suites of the Northern Bonfim Metamorphic Complex (normalized values after Massuda et al. 1973); 7B -MORB-normalized spider gram of the mafic suites from the Northern Bonfim Metamorphic Complex (normalized values after Pearce 1982, 1983).

Figura 7A - padrão condrítico de ETR das suites maficas da porção setentrional do Complexo Metamórfico Bonfim normalizado pelos valores de Massuda et al. (1973); 7B - Diagrama de variação das suites maficas da porção setentrional do Complexo Metamórfico Bonfim normalizado pelos valores de Pearce (1982,1983).

Table 3 - Major (wt \%), trace (ppm), and rare earth (ppb) elements analyses of representative samples of the Paraopeba and Candeias Amphibolites.

Table 3 - Análises químicas representativas de elementos maiores (\% em peso), tracos (ppm) e Terras Raras (ppb) de amostras representativas dos Anflbiolitos Paraopeba e Candeias.

\begin{tabular}{|c|c|c|c|c|c|c|c|c|c|c|c|c|c|c|c|c|c|}
\hline \multicolumn{9}{|c|}{ Paraopeba Amphibolite** } & \multicolumn{9}{|c|}{ Candeias Amphibolite** } \\
\hline Samples & AK7 & BN2 & CL7 & CN5-2 & EK9 & EK10 & FN1 & $\mathbf{N} 12$ & HK4-A & $\mathrm{JGI}-\mathrm{C}$ & JG4-A & JG4:L & JH5.A & $\mathrm{KH} 3 \mathrm{~A}$ & KH3-L & Lل10 & MLE-C \\
\hline (\%) $\mathrm{SiO}_{2}$ & 51.20 & 49.10 & 49.20 & 49.10 & 50.50 & 50.90 & 48.60 & 49.30 & 50.10 & 49.00 & 50.10 & 49.40 & 50.60 & 51.30 & 49.60 & 49.20 & 51.20 \\
\hline $\mathrm{TiO}_{2}$ & 1.60 & 1.80 & 1.80 & 1.80 & 1.50 & 1.50 & 1.00 & 2.60 & 2.60 & $1.60^{\circ}$ & 1.90 & 2.10 & 1.60 & 2.00 & 1.70 & 1.90 & 1.20 \\
\hline $\mathrm{Al}_{2} \mathrm{O}_{3}$ & 14.30 & 14.40 & 14.90 & 14.30 & 14.50 & 15.10 & 15.80 & 12.50 & 15.80 & 13.60 & 13.10 & 12.60 & 14.20 & 13.10 & 12.90 & 13.20 & 14.00 \\
\hline $\mathrm{Fe}_{2} \mathrm{O}_{3}$ & 1.70 & 2.70 & 1.80 & 2.10 & 1.50 & 1.30 & 1.80 & 2.20 & 3.60 & 2.90 & 3.20 & 2.10 & 1.30 & 1.50 & 2.60 & 1.20 & 1.80 \\
\hline $\mathrm{FeO}$ & 10.90 & 10.40 & 10.20 & 10.30 & 10.70 & 10.70 & 8.30 & 14,10 & 8.70 & 10.40 & 11.50 & 12.90 & 12.00 & 13.60 & 13.10 & 12.90 & 11.10 \\
\hline $\mathrm{MnO}$ & 0.19 & 0.21 & 0.20 & 0.20 & 0.21 & 0.21 & 0.18 & 0.25 & 0.19 & 0.21 & 0.23 & 0.23 & 0.19 & 0.22 & 0.25 & 0.22 & 0.19 \\
\hline $\mathrm{MgO}$ & 5.00 & 6.00 & 6.10 & 6.20 & 5.60 & 4.70 & 7.80 & 4.90 & 3.10 & 6.40 & 5.60 & 5.60 & 5.60 & 4.30 & 5.10 & 6.00 & 5.90 \\
\hline $\mathrm{CaO}$ & 10.20 & 9.70 & 10.10 & 9.50 & 10.40 & 10.20 & 10.50 & 9.60 & 9.20 & 10.70 & 10.30 & 10.70 & 10.80 & 9.90 & 10.20 & 10.60 & 11.10 \\
\hline $\mathrm{Na}_{2} \mathrm{O}$ & 2.00 & 2.50 & 2.60 & 2.70 & 2.40 & 2.50 & 2.60 & 2.60 & 4.10 & 2.30 & 2.50 & 2.50 & 2.00 & 2.40 & 2.70 & 2.50 & 2.10 \\
\hline $\mathrm{K}, \mathrm{O}$ & 0.71 & 1.10 & 1.00 & 1.80 & 0.84 & 0.94 & 1.70 & 0.40 & 0.28 & 0.54 & 0.49 & 0.49 & 0.45 & 0.45 & 0.49 & 9.36 & 0.28 \\
\hline $\mathrm{P}_{2} \mathrm{O}_{3}$ & 0.15 & 0.22 & 0.19 & 0.19 & 0.13 & 0.14 & 0.11 & 0.27 & 0.38 & 0.16 & 0,28 & 0.21 & 0.16 & 0.19 & 0.19 & 0.21 & 0.10 \\
\hline LOI & 1.74 & 1.72 & 1.72 & 1.72 & 1.57 & 3.69 & 1.71 & 1.02 & 1.82 & 1.97 & 0.58 & 0.86 & 1.03 & 0.95 & 0.82 & 1.42 & 0.92 \\
\hline Total & 99.72 & 99.85 & 99.81 & 99.91 & 99.86 & 99.88 & 100.00 & 99.74 & 99.87 & 99.78 & 99.78 & 99.69 & 99.93 & 99.91 & 99.65 & 99.71 & 99.89 \\
\hline$(\mathrm{ppm}) \mathrm{Cr}$ & 148 & 122 & 158 & 120 & 162 & 136 & 340 & 128 & 62 & 200 & 120 & 220 & 220 & 132 & 136 & 230 & 340 \\
\hline $\mathrm{Ni}$ & 108 & 118 & 166 & 106 & 112 & 94 & 180 & 126 & 78 & 100 & 86 & 142 & 146 & 102 & 112 & 156 & 158 \\
\hline $\mathrm{Co}$ & 50 & 49 & 54 & 46 & 50 & 51 & 45 & 51 & 64 & 44 & 43 & 58 & 52 & 66 & 58 & 60 & 84 \\
\hline $\mathrm{Sc}$ & . & - & - & - & $=$ & - & $=$ & . & $\%$ & $=$ & - & - & - & - & . & - & . \\
\hline v & 298 & 338 & 348 & 308 & 348 & 278 & 258 & 398 & 308 & 288 & 228 & 458 & 228 & 288 & 438 & 468 & 268 \\
\hline $\mathrm{Cu}$ & 50 & 47 & 34 & 81 & 63 & 69 & 16 & 103 & 63 & 103 & 75 & 66 & 100 & 94 & 81 & 113 & 88 \\
\hline $\mathrm{Pb}$ & - & - & - & - & - & . & - & * & 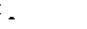 &. & - & 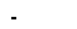 & - & - & . & - & - \\
\hline Zn & 143 & 133 & 130 & 140 & 133 & 133 & 100 & 197 & 143 & 147 & 187 & 167 & 127 & 137 & 137 & 137 & 113 \\
\hline $\mathrm{s}$ & 1300 & 1000 & 700 & 1300 & 1200 & 1300 & 800 & 1600 & 1400 & 1000 & 1000 & 1100 & 1100 & 1100 & 1300 & 1300 & 900 \\
\hline $\mathbf{R b}$ & 26 & 38 & 37 & 73 & 23 & 24 & 81 & $<10$ & $<10$ & 24 & $<10$ & $<10$ & 10 & 17 & 15 & 10 & $<10$ \\
\hline $\mathrm{Ba}$ & 140 & 120 & 160 & 230 & 130 & 150 & 130 & 41 & 20 & 72 & 84 & 74 & 75 & 96 & 110 & 67 & 24 \\
\hline SI & 130 & 170 & 150 & 180 & 120 & 120 & 170 & 91 & 480 & 110 & 100 & 88 & 110 & 100 & 97 & 94 & 120 \\
\hline $\mathrm{Nb}$ & 33 & 42 & 42 & 28 & 44 & 36 & 24 & 42 & 32 & $<20$ & 20 & 52 & $<20$ & $<20$ & 36 & 58 & $<20$ \\
\hline $\mathrm{Zr}$ & 176 & 178 & 178 & 160 & 162 & 148 & 98 & 230 & 260 & 134 & 172 & 240 & 156 & 210 & 182 & 210 & 132 \\
\hline$Y$ & 66 & 70 & 69 & 59 & 70 & 67 & 48 & 84 & 100 & 56 & 77 & 104 & 64 & 86 & 74 & 82 & 70 \\
\hline $\mathbf{F}$ & 400 & 300 & 400 & 300 & 300 & 300 & 800 & 400 & 300 & 200 & 300 & 300 & 200 & 300 & 300 & 300 & 200 \\
\hline $\mathrm{Cl}$ & 230 & 790 & 670 & 590 & 230 & 200 & $<20$ & 480 & 150 & 180 & 280 & 310 & 130 & 170 & 200 & 190 & $<20$ \\
\hline (ppb) La & 11.49 & - & 11.25 & - & - & 11.66 & $=$ & $*$ & - & 7.84 & - & 13.75 & 9.82 & - & . & - & - \\
\hline $\mathrm{Ce}$ & 31.78 & - & 38.43 & - & - & 30.79 & - & - & - & 29.20 & . & 41.54 & 29.26 & . & . & . & + \\
\hline Nd & 18.74 & - & 18.36 & - & - & 16.67 & - & - & - & 14.64 & - & 23.17 & 16.59 & - & - & . & - \\
\hline Sm & 4.92 & - & 4.88 & - & - & 4.44 & - & - & - & 4.11 & - & 6.87 & 4.72 & * & - & . & + \\
\hline Eu & 1.39 & - & 1.30 & . & - & 1.30 & * & . & . & 1.14 & . & 1.67 & 1.22 & * & . & $=$ & . \\
\hline Gd & 4.09 & - & 3.49 & - & - & 3.70 & - & - & . & 3.22 & - & 5.58 & 3.87 & - & - & - & - \\
\hline Dy & 5.98 & - & 4.69 & - & - & 5.31 & - & - & - & 4.45 & - & 7.37 & 5.40 & . & - & $*$ & - \\
\hline Ho & 1.25 & - & 0.97 & - & - & 1.00 & - & - & - & 0.93 & - & 1.50 & 1.13 & . & - & . & - \\
\hline Er & 3.62 & - & 2.98 & - & - & 3.21 & - & . & . & 2.83 & . & 4.55 & 3.34 & - & . & $=$ & - \\
\hline Yb & 3.37 & - & 2.65 & . & - & 2.97 & . & . & . & 2.45 & . & 4.04 & 2.89 & - & . & - & - \\
\hline Lu & 0.38 & - & 0.35 & - & - & 0.35 & $=$ & - & - & 0.29 & $=$ & 0.50 & 0.36 & $=$ &. & - & - \\
\hline
\end{tabular}


have been obtained by SHRIMP in the Campo Belo Metamorphic Complex, located southwest of the NBMC.

Table 4 and Figure 8 present the Sm-Nd whole rock data of gneisses, amphibolites, tonalites, and granites of the NBMC recalculated from Teixeira et al. (1996).

The $\mathrm{T}_{\mathrm{DM}}$ crust formation ages range from 2940 to $3240 \mathrm{Ma}$ for the six NeoArchaean units of the NBMC. The oldest age (3240 Ma) was calculated for the SNG. This rock presents an anomalous low $\mathrm{f} \mathrm{Sm} / \mathrm{Nd}$ ratio (0.23) when compared to the AFG, ST and BG (0.43-0.41; Table 4). Therefore, the SNG may have a $\mathrm{Sm} / \mathrm{Nd}$ fractionated system and thus its $\mathrm{T}_{\mathrm{DM}}$ will be not considered hereafter.

The PA and CA (samples 120 and 198; Table 4) yield comparable $\mathrm{T}_{\mathrm{DM}}$ ages (3120 and $2960 \mathrm{Ma}$.) and $\mathrm{f} \mathrm{Sm} / \mathrm{Nd}$ ratios $(0.16,0.18)$. As a whole, the geochronological pattern supported by the $\mathrm{T}_{\mathrm{DM}}$ crust formation ages are compatible with the oldest $\mathrm{U}-\mathrm{Pb}$ ages already reported in the SSFC, and support that a significant differentiation/accretion event preceding ca. 300-400 Ma the NBMC took place in the southern part of the Sao Francisco Craton.

The $£ N d$ values of AFG, SNG, ST and BG calculated for $\mathrm{t}$ $=2700 \mathrm{Ma}$ (final stage of the RVTE -NBMC) are all slightly negative (-0.9 to -2.8$)$, suggesting pre-existing continental crust in the RVTE (2780-2700 Ma). This agrees with the U-Pb inherited-age pattern of different rock units in the SSFC. In particular, the variation of epsilon values of the ST (-0.9 and $-2.5)$ and of the BG (-0.9 and -2.8$)$ points to different proportions of sialic material in the magma genesis. On the other hand, the amphibolites yield a $\varepsilon_{\mathrm{Nd}}(2700 \mathrm{Ma})$ of -0.1 (PA) and +0.6 (CA), suggesting their genetic relationship with the RVTE.

In figure 8 , the calculated $\varepsilon_{\mathrm{Nd}}$ values versus time provide additional details for the NeoArchaean crustal evolution of the NBMC (SNG sample is not plotted - see comments above). As usual, the isotope trends shown (lines 1 to 6 ) are dependent on the ${ }^{147} \mathrm{~S} \mathrm{~m} / \mathrm{N} \mathrm{d}^{14} 4$ ratios of each of the analyzed rock units, as illustrated by the higher ratios in the amphibolites $(2,5)$, as compared to the lower of the tonalites (4) and granites (6). The AFG samples (1) has Sm-Nd ratios intermediate between the amphibolites and the ST and BG samples.

In general, country rocks show a relatively uniform isotope trend from 3150 to $2940 \mathrm{Ma}\left(\varepsilon_{\mathrm{Nd}}\right.$ between -32.4 and -26.3 ), as indicated by the field limited by lines 1 and 6 (Fig. 8). This supports the interpretation that the NBMC originated during a single accretion/differentiation event. Moreover, the distinct isotopic trends of the amphibolites $\left(\varepsilon_{\mathrm{Nd}}=-12\right.$ and -11) indicates the participation of juvenile components during the RVTE.

As a whole, the Sm-Nd interpretation, coupled with the inferences from the $\mathrm{U}-\mathrm{Pb}$ geochronology, indicates that older crustal materials participated in the NeoArchaean evolution of the NBMC. The Rb-Sr (isochronic and errocronic ages) and $\mathrm{K}-\mathrm{Ar}$ (mineral apparent ages) in the range 2200 - $500 \mathrm{Ma}$ of different units of the NBMC (Table 1) indicate that the Complex was affected only by low-grade Proterozoic overprinting (Carneiro 1992, Carneiro \& Teixeira 1992, Carneiro et al. 1993).

THE TECTONIC CRUSTAL EVOLUTION OF THE QF AND SSFC The U-Pb radiometric ages (Table 1) of the NBMC rocks indicate that the time span of the main NeoArchaean RVTE (2780-2700 Ma) is less than $80 \mathrm{Ma}$. Comparable $\mathrm{U}-\mathrm{Pb}$ zircon ages are reported from Archaean

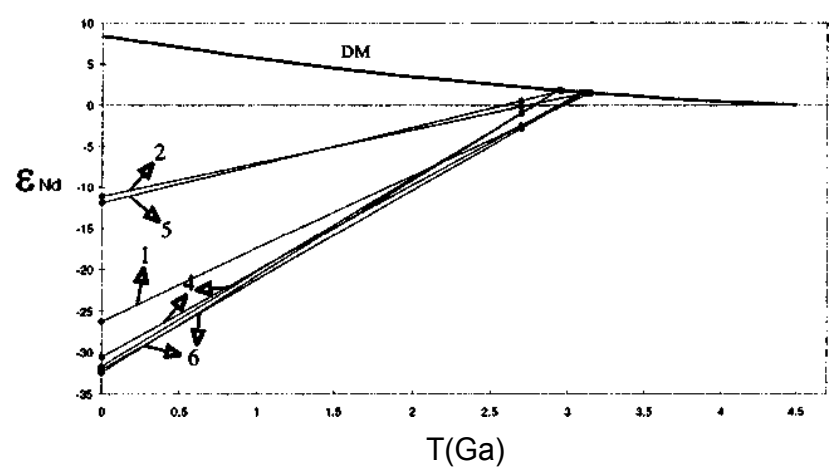

Figure $8-\varepsilon_{\mathrm{Nd}}$ diagram versus time for the Northern Bonfim Metamorphic Complex units. Keys: 1 - Alberto Flores Gneiss; 2 - Paraopeba Amphibolite;4 - Samambaia Tonalite; 5 Candeias Amphibolite; 6 - Brumadinho Granite. Figure 8 - Diagrama $\varepsilon_{\mathrm{Nd}} \mathrm{x}$ tempo para a poção norte do Complexo Metamorfico Bonfim. 1 - Gnaisse Alberto Flores; 2 - Anflbolito Paraopeba; 4 - Tonalito Samambaia; 5 - Anflbolito Candeias; 6 - Granito Brumadinho.

Table 4 - Sm-Nd analytical data for the Northern Bonfim Metamorphic Complex. Units: 1 - Alberto Flores Gneiss; 2 -Paraopeba Amphibolite; 3 - Souza Noschese Gneiss; 4 -Samambaia Tonalite; 5 - Candeias Amphibolite; 6 - Brumadinho Granite.

Tabela 4 - Dados analíticos Sm-Nd da porção norte do Complexo Metamorfico Bonfim. Unidades: 1 - Gnaisse Alberto Flores; 2 - Anflbolito Paraopeba; 3 Gnaisse Souza Noschese; 4 - Tonalito Samambaia; 5 - Anflbolito Candeias; 6 - Granito Brumadinho.

\begin{tabular}{|cccccccccc|}
\hline Units & Sample & Lab. no. & ${ }^{147} \mathrm{Sm} /{ }^{144} \mathrm{Nd}$ & ${ }^{143} \mathrm{Nd} / /^{144} \mathrm{Nd}$ & $\varepsilon_{\mathrm{Nd}}(\mathrm{tp})$ & $\mathrm{f}_{(\mathrm{SmNd})}$ & $\varepsilon_{\mathrm{Nd}}(\mathrm{TDM})$ & $\varepsilon_{\mathrm{Nd}(2700 \mathrm{Ma})}$ & $\mathrm{T}_{\mathrm{DM}}(\mathrm{Ma})$ \\
\hline 1 & 11.1 & 082 & $0.1275 \pm 0.0001$ & $0.511291 \pm 0.000025$ & -26.28 & -0.35 & 1.54 & -2.43 & 3150 \\
2 & 120 & 142 & $0.1650 \pm 0.0002$ & $0.512071 \pm 0.000038$ & -11.06 & -0.16 & 1.55 & -0.15 & 3120 \\
3 & 243.6 & 083 & $0.1514 \pm 0.0001$ & $0.511749 \pm 0.000030$ & -17.34 & -0.23 & 1.38 & -1.74 & 3240 \\
4 & $625 \mathrm{~F}$ & 072 & $0.1073 \pm 0.0019$ & $0.511014 \pm 0.000031$ & -31.68 & -0.45 & 1.86 & -0.88 & 2940 \\
4 & $656 \mathrm{C}$ & 073 & $0.1152 \pm 0.0002$ & $0.511073 \pm 0.000043$ & -30.53 & -0.41 & 1.59 & -2.47 & 3090 \\
5 & $\mathrm{M}-301$ & 198 & $0.1604 \pm 0.0002$ & $0.512027 \pm 0.000023$ & -11.92 & -0.18 & 1.79 & +0.58 & 2960 \\
6 & 11.15 & 070 & $0.1053 \pm 0.0008$ & $0.510976 \pm 0.000041$ & -32.42 & -0.46 & 1.84 & -0.96 & 2940 \\
6 & 11.18 & 071 & $0.1114 \pm 0.0001$ & $0.510991 \pm 0.000028$ & -32.13 & -0.43 & 1.60 & -2.75 & 3100 \\
\hline
\end{tabular}

$\mathrm{T}_{\mathrm{DM}}$ ages recalculated from Teixeira et al. (1996).

See text for details. Isotope ratios were measured based on 2 a errors. $\varepsilon_{\mathrm{Nd}(\mathrm{tp})}$ is

the present day values. 
gneisses of the Kaapvaal Craton (Kamo et al. 1995, Robb et al. 1992) and of the Murchison Province, Western Australia (Wiedenbeck \& Watkins 1993). This implies that worldwide crustal growth occurred during the first half of the NeoArchaean. Moreover, the Sm-Nd isotopic evidence coupled with $\mathrm{Pb}$ inherited age components of the NBMC and other rock units within the SSFC rocks suggest that the primary crustal evolution goes back to 3300-3200 Ma (Fig. 9). However, the tectonic evolution of the NBMC and QF sialic crust, during the Meso- to NeoArchaean period, suggests a complex geological evolution, as illustrated in the cartoon sequence of fig. 9 .
This global tectonic model implies the existence of a MesoArchaean continental crust fragment of trondhjemitic composition that moved towards the convergent margin of two MesoArchaean oceanic plates (Fig. 9A). Due to the buoyancy of this MesoArchaean continental fragment, another convergent zone developed on the opposite margin (Fig. 9B). The two subduction zones induced a pervasive mantle melting (Fig. 9C), leading to a MesoArchaean plume located below the continental fragment (Fig. 9B, 9C).

The magma extracted from the plume migrated upwards and accumulated in magmatic reservoirs under the sialic crust (Fig. 9B). This magmatic reservoir was the primary source for

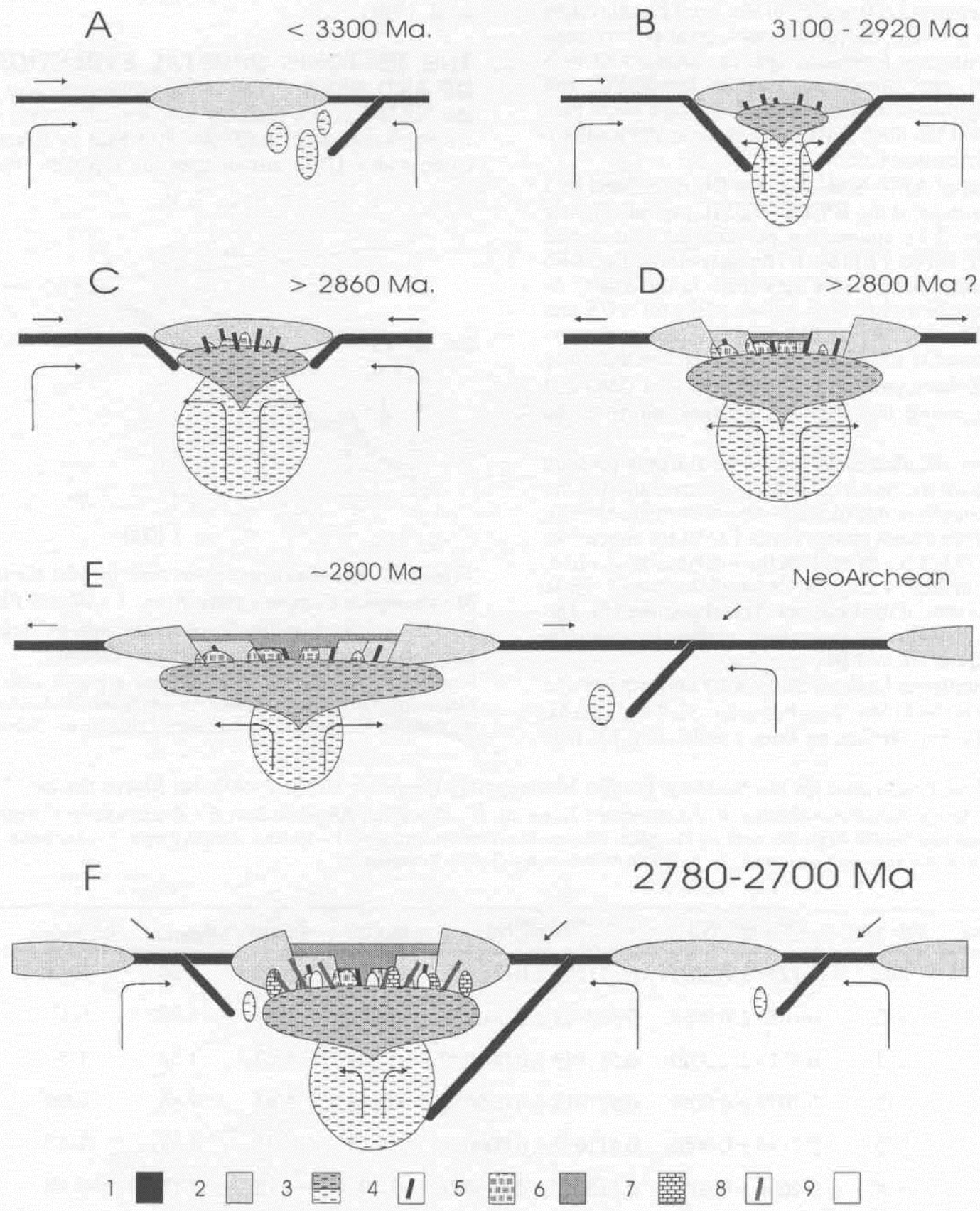

Figure 9 - Cartoon illustrating Meso- to NeoArchaean tectonic evolution of the Quadrilatero Ferrifero sialic crust. Keys: 1 Oceanic Crust; 2 - Continental Crust (Protolith of the Alberto Flores Gneiss?); 3 - Mantelic Plume and magma reservoir; 4 Protolith of the Paraopeba Amphibolite; 5 - Protolith of the Souza Noschese Gneiss; 6 - Basin and Vulcano-Sedimentary Sequence of the Rio das Velhas Greenstone Belt; 7 - Samambaia Tonalite; 8 - Candeias Amphibolite; 9 - Brumadinho Granite. Figura 9 - Ilustração da evolução da crosta siálica meso- a neoarqueana do Quadrilatero Ferrífero. 1 - Crosta oceânica; 2 - Crosta continental (Protólito do Gnaisse Alberto Flores?); 3 - Pluma mantélica e reservatório de magma; 4 - Protólito do Anfibolito Paraopeba; 5 - Protólito do Gnaisse Souza Noschese; 6 - Bacia e seqiiencia vulcano-sedimentar do Greenstone Belt Rio das Velhas; 7 - Tonalito Samambaia; 8 - Anfibolito Candeias; 9 - Granito Brumadinho. 
the tholeiitic magmas of the PA, mafic and ultramafic magmas of the RVGR, calc-alkaline magma of the ST, tholeiitic magma of the CA and granitic magma of the BG (Fig. 9B, 9C, 9D, 9E, 9F).

The PA, as supported by the Sm-Nd evidence (Table 4), shows a within-plate tholeiitic composition, consistent with the emplacement into a pre-existent continental crust (Carneiro 1992, Carneiro et al. 1998). As pointed out, the SNG contains xenoliths of the AFG and is intruded by the $2780 \mathrm{Ma}$ ST. The geochemistry and Sm-Nd data of the SNG suggest partial melting of the MesoArchaean trondhjemitic crust (Fig. 9C). The formation of the SNG could be contemporary with Jhe migmatitic event of the BHG, dated at 2860 Ma (Noce 1995).

The growth of the magmatic reservoir braked the MesoArchaean subduction zones and an extension of the MesoArchaean sialic crust (Fig. 9D). This episode originated the RVGB volcano-sedimentary basin (Figs. 9D, 9E). As pointed out by Golia et al. (1996) and Golia (1997), the NeoArchaean NBMC sialic crust preceded the formation of the RVGB volcano-sedimentary basin. This is indicated by the occurrence of tonalite and dacite boulders in the late terrigenous sequence of the RVGB. Additionally, the sedimentary matrix of the terrigenous sequence was supplied from a granitic source. This agrees with composition of two NBMC lithostratigraphic units (ST and SNG).

Several episodes of oblique collisional tectonics led to the inversion of the RVGB volcano-sedimentary basin (Figs. 9E, 9F), as recorded by the widespread dextral NS shear zones in the QF region (Endo \& Carneiro 1996, Endo et al. 1996).

The RVTE played a major role in the formation of the NBMC and QF sialic crust (Carneiro 1992, Carneiro et al. 1996, 1998). During this event, which started at $2780 \mathrm{Ma}$, the MesoArchaean continental crust was reworked $(2772 \pm 6 \mathrm{Ma}$ zircon overgrowth in the AFG) and intruded by the calc-alka- line ST $(2780+3 /-2 \mathrm{Ma})$ and tholeiitic magmas (CA). Felsic volcanic activity also took place in the RVGB (2776-2772 Ma; Machado et al. 1992). At the end of the RVTE the BG magma was emplaced into the sialic crust at $2703+24 /-20 \mathrm{Ma}$ (Fig. 9E).

The geological characteristics of RVTE, supported by the geochemical signature of NBMC rocks, coupled with widespread metamorphism, calc-alkaline magmatism in both the sialic crust and RVGB, and the tholeiitic volcanics suggest that the QF and SSFC formed in a NeoArchaean convergent margin setting (Carneiro 1992, Machado \& Carneiro 1992, Carneiro et al 1998). The geological setting of the NBMC and the proximity of the contemporaneous RVGB indicate an ensialic tectonic environment of the later can be stated.

Due to the new oblique continental collisions, the NeoArchaean continental plate was enlarged, creating the NeoArchaean SSFC terranes. Post Archaean low grade metamorphism of the NBMC rocks is indicated by heterogeneous $\mathrm{Rb}-\mathrm{Sr}$ whole rock and $\mathrm{K}-\mathrm{Ar}$ mineral apparent ages between $2200 \mathrm{Ma}$ and $500 \mathrm{Ma}$ (Table 1). The resetting of the $\mathrm{Rb}-\mathrm{Sr}$ and K-Ar systems of the NBMC rocks could be related to extensional episodes, formation of sedimentary basins, (Carneiro et al. 1998), continental collision or erogenic belt formation, and crustal uplift. This provide conditions to the emplacement of the anorogenic mafic intrusions in the SSFC during the Proterozoic evolution (e.g. Marshak \& Alkmim 1989, Carneiro 1992, Carneiro etal. 1998).

Acknowledgments To CNPq and FAPEMIG for the research grants to analytical procedures at CPGeo/USP, GEOSOL, and GEOTOP/UQAM/Montreal. To H. A. Nalini Jr., J. F. M. Hipperti, H. Jordt-Evangelista, and two anonymous reviewers for their valuable comments and suggestions for improving the manuscript.

\section{REFERENCES}

Amaral, G.; Cordani, U. G.; Kawashita, K.; Reynolds, J. H. 1966. Potassium-argon dates of basaltics rocks from southern Brazil. Geochimica et Cosmochimica Acta, 30:159-189.

Babinski, M.; Chemale Jr., F.; Schmus, W. R. Van 1995. The Pb/Pb age of the Minas Supergroup carbonate rocks, Quadrilatero Ferrífero, Brazil, Precambrian Research, 72:235-245.

Carneiro, M. A. 1992. O Complexo Metamorfico Bonfim Setentrional (Quadrilatero Ferrifero, Minas Gerais): Litoestratigrafia e Evolução Geologica de urn Segmento de Crosta Continental do Arqueano. Sao Paulo, 233p. Tese de Doutoramento, Institute de Geociencias da Universidade de São Paulo.

Carneiro, M. A. \& Teixeira, W. 1992. Discordancia de idades radiometricas U-Pb e Rb-Sr no craton do Sao Francisco meridional: evidencias a partir do Complexo Metamórfico Bonfim Setentrional, Quadrilatero Ferrifero, Minas Gerais. In: Congresso Brasileiro de Geologia, 37, São Paulo, 1992. Resumos... São Paulo, SBG, p. 189-190.

Carneiro, M. A. \& Teixeira, W. 1993. Geoquimica e geocronologia dos diques maficos precambrianos do Complexo Metamórfico Bonfim Setentrional, regiao meridional do Craton do Sao Francisco, Brasil. In: Congresso Geoquimico dos Países de Língua Portuguesa, II, Porto, 1993. Memorias ... Porto, p. 15-19.

Carneiro, M. A.; Teixeira, W. \& Machado, N. 1993. Evolução geologica policíclica de terrenos granito-greenstone do Arqueano Superior do Craton do Sao Francisco Meridional: Um exemplo a partir do Complexo Metamdrfico Bonfim Setentrional. In: Simpdsio do Craton do Sao Francisco, II, Salvador, 1993. Anais... Salvador, SBG, pp. 70-74

Carneiro, M. A.; Teixeira, W. \& Machado, N. 1994. Geological evolution of a sialic Archaean crustal fragment from the Quadrilátero Ferrifero in eastern-central Brazil, based on U-Pb, Sm-Nd, $\mathrm{Rb}-\mathrm{Sr}$, and $\mathrm{K}-\mathrm{Ar}$ isotopic constraints. Terra Noxtra, 2:12-13.

Carneiro, M. A.; Noce, C. M.; Teixeira, W. 1995. Evolução policiclica do Quadrilatero Ferrifero: uma andlise fundamentada no conhecimento atual da geocronologia $\mathrm{U}-\mathrm{Pb}$ e geoquimica isot6pica $\mathrm{Sm}-\mathrm{Nd}$. Revista da Escola de Minas, 48:264-273.
Carneiro, M. A.; Teixeira, W.; Noce, C. M.; Fernandes, R. A. 1996. Archaean growth processes in the Quadrilatero Ferrifero: A geochronological $\mathrm{U}-\mathrm{Pb}$ and $\mathrm{Sm}-\mathrm{Nd}$ approach to the Rio das Velhas Event $(2780-2700$ Ma). In: Simpdsio de Terrenos Arqueanos da Plataforma Sul-americana, Brasilia. 1996. Anais ... Brasilia, SBG, p. 59 e 60.

Carneiro, M. A. Jordt-Evangelista, H. \& Teixeira, W. 1997. Eventos Magmdticos Arqueanos de Natureza Calcio-alcalina e Tholeiitica no Quadrildtero Ferrifero e suas Implicações Tectonicas. Revista Brasileira de Geociencias, 27:121-128

Carneiro, M. A. Carvalho Junior, I. M. de \& Teixeira, W. 1998. Petrologia Geoquimica e Geocronologia dos Diques Maficos do Complexo Metamdrfico Bonfim Setentrional (Quadrildtero Ferrifero) e suas implicafoes Tectonicas na Evolucao Crustal do Craton do Sao Francisco Meridional. Revista Brasileira de Geociencias (In press).

Castro, L. O. 1994. Genesis of Banded Iron Formation. Economic Geology, 89:1384-1397.

Condie, K. C. 1981. Archaean greenstone belts. Amsterdam. Elsevier, 434 $P$.

Condie, K. C. 1989. Origin of the Earth's crust. Palaeogeography, Palaeoclimatology, Palaeoecology, 75:57-81.

Corfu, F. \& Stott, G. M. 1986. U-Pb ages for late magmatism a regional deformation in the Shebadandowan belt, Superior Province, Canada. Canadian Journal of Earth Sciences, 23:1075-1082.

Davis, D. W. 1982. Optimum linear regression and error estimation applied to U-Pb data. Canadian Journal of Earth Sciences, 19:2141-2149.

DePaolo, D. J., 1981. A neodymium and strontium isotopic study of the Mesozoic calc-alkaline granitic batholiths of Sierra Nevada and Peninsular Ranges, California. Journal of Geophysical Research, 86:10470-10488

Dorr II, J. Van N. 1969. Physiographic, Stratigraphic and Structural Development of the Quadrilátero Ferrifero, Minas Gerais, Brazil. $U$. S. Geological Survey Professional Paper, 641(A), 110p.

Endo, I. \& Carneiro, M. A. 1996. O regime tectSnico do Neoarqueano no Quadrilátero Ferrifero: um modelo transpressional. In: Congresso Brasileiro de Geologia., 39, Salvador, 1996. Anais... Salvador, SBG. vol. 1, p. 414-416. 
Endo, I.; Carneiro, M. A.; Machado, R. 1996. O Complexo Metamorfico Bafao: Um elemento estrutural anisotropico na deformação do Supergrupo Rio das Velhas -Q. F., M. G. In: Congresso Brasileiro de Geologia, 39, Salvador, 1996. Anais... Salvador, SBG. vol. 1, p. 411-413.

Golia, A.; Carneiro, M. A.; Oliveira, C. G. de 1996. Meta-conglomerados da regiao de Sao Bartolomeu, Quadrildtero Ferrifero, Minas Gerais: Natureza, area fonte e implicações tectônicas. In: Congresso Brasileiro de Geologia, 39, Salvador, 1996. Anais... Salvador, SBG. vol. 2, p. 16-19.

Golia, A. 1997. Petrografia e Geoquimica dos metassedimentos do Grupo Nova Lima, Greenstone Belt Rio das Velhas na Regiao de Sao Bartolomeu: Modelagem de Area-Fonte, Proveniencia e Ambiente Tectonico. Ouro Preto. 142p. Disserta9ao de Mestrado, Escola de Minas da Universidade Federal de Ouro Preto.

Gomes, N. S. 1985. Petrologisch-geochemische Untersuchugen im Bafao-Komplex Eisernes Viereck, Minas Gerais, Brasilien. Clausthal. 209 p. (Dissertation, Mathematisch-Naturwissenchaftlichen Fakultat, Technische Universitat Clausthal).

Gomes, N. S. 1986. Determinações Geotermometricas e Geobarometricas em Parageneses Minerais de Alto Grau Metamorfico no Complexo do Bafao, Quadrilatero Ferrifero -Minas Gerais. In: Congresso Brasileiro de Geologia, 34., Goiânia, 1986. Anais... Goiânia, SBG. v. 4, p. 1424-36.

Gomes, N. S. \& Muller, G. 1987. Caracterização Quimica de Parageneses Minerais de Alto Grau Metam6rfico no Complexo Bacão, Quadrilatero Ferrifero, Minas Gerais. Revista da Escola de Minas, 40(1):25-36.

Herz, N. 1970. Gneissic and Igneous Rocks of the Quadrilatero Ferrifero, Minas Gerais, Brazil. U. S. Geological Survey Professional Paper, 641(B): $1-58$

Irvine, T. N. \& Baragar, W. R. A. 1971. A Guide to the Chemical Classification of the Common Volcanic Rocks. Canadian Journal of Earth Sciences, 8:523-548.

Kamo, S. L.; Key, R. M.; Daniels, L. R. M. 1995. New evidence for NeoArchaean hydrothermally altered granites in south-central Botswana. Journal of the Geological Society of London, 152:747-750.

Kroch, T. E. 1973. A low-contamination method for hidrothermal decomposition of zircon an extraction of $\mathrm{U} \mathrm{a} \mathrm{Pb}$ for isotopic age determinations. Geochimica et Cosmochimica Acta, 37:485-494.

Krogh, T. E. 1982a. Improved accuracy of U-Pb dating by selection of more concordant fractions using a high gradient magnetic separation technique. Geochimica et Cosmochimica Acta, 46:631-636.

Krogh, T. E. 1982b. Improved accuracy of U-Pb ages by the creation of more concordant systems using an air abrasion technique. Geochimica et Cosmochimica Acta, 46:637-649.

Ladeira, E. A. 1980. Metallogenesis of Gold at the Morro Velho Mine, and in Nova Lima District, Ouadrilatero Ferrifero, Minas Gerais, Brazil. London, 272 p. (Ph. D Thesis, University of Western Ontario).

Ladeira, E. A. \& Viveiros, J. F. M. 1984. Hipotese sobre a estruturacao do Quadrilátero Ferrífero com base nos dados disponiveis. Boletim Especial (Sociedade Brasileira de Geologia, Niicleo de Minas Gerais), 4:1-14.

Machado, N. \& Carneiro, M. A. 1992. U-Pb evidence of late Archaean Tectonothermal activity in southern Sao Francisco shield, Brazil. Canadian Journal of Earth Sciences, 29:2341-2346.

Machado, N.; Goulet, N.; Gariepy, C. 1989. U-Pb geochronology of reactivated Archaean basement and of Hudsonian metamorphism in the northern Labrador Trough. Canadian Journal of Earth Sciences, 26:1-15.

Machado, N.; Phillipe, S.; Davi, J.; Gariepy, C. 1991. Geochronologie U-Pb du territorie quebecois: Fosses du Labrador et de I'Ungava et Sous-province de Pontiac. Ministere de 1'Energie et des Ressources, MB 91-07, 50p

Machado, N.; Noce, C. M.; Oliveira, O. A. B. de; Ladeira, E. A. 1992. U-Pb geochronology of Archaean magmatism and Proterozoic metamorphism in the Quadrilatero Ferrifero, southern Sao Francisco Craton, Brazil. Geological Society American Bulletin. 104:1221 -1227.

Machado, N.; Noce, C. M.; Feng, R. 1993. Idades ${ }^{207} \mathrm{~Pb} /{ }^{206} \mathrm{~Pb}$ de zircoes detriticos de rochas meta-sedimentares da regiSo do Quadrilatero Ferrifero, sul do Craton do S5o Francisco. Considera9oes sobre areas-fontes e idades de sedimentação. In: Simpósio do Craron do Sao Francisco, II, Salvador, 1993. Anais... Salvador, SBG, p 149-151.

Machado, N.; Schrank, A.; Noce, C. M.; Gauthier, G. 1996. Ages of detrital zircon from Archaean-Paleoproterozoic sequences: Implications for Greenstone Belt setting and evolution of a Transamazonian foreland basin in Quadrilatero Ferrifero, southeast Brazil. Earth and Planetary Science Letters, 141(1-4):259-276.

Marshak, S. \& Alkmim, F. F. 1989. Proterozoic Contraction/Extension Tectonics of the Southern São Francisco Region, Minas Gerais, Brazil. Tectonics, 8(3):555-571.
Martin, H. 1987. Petrogenesis of Archaean Trondhjemites, Tonalites and Granodiorites from Eastern Finland: Major and Trace Element Geochemistry. Journal of Petrology, 28:921-953.

Mascarenhas, J. de F.; Pedreira, A. J.; Misi, A.; Motta, A. C.; Sa, J. H. da S. 1984. Provmcia Sao Francisco. In: Almeida, F. F. M de \& Hasui, Y. (Eds.) O Pre-Cambriano do Brasil. Sao Paulo, Edgar Blucher, p. 46-122.

Massuda, A.; Nakamura, N.; Tanaka, T. 1973. Fine structures of mutually normalized rare-earth pattern of chondrites. Geochimica et Cosmochimica Acta, 36:239-348.

McGregor, V. R.; Nutman, A. P.; Friend, C. R. L. 1985. The Archaean geology of the Godthåbsfjord region, Southern West Greenland. In: L. D. ASHWALL (Ed.). Early crustal genesis: The world's oldest rocks LPI Technical Report 86-04, p. 113-184.

Noce, C. M. 1995. Geocronologia dos eventos magmdticos, sedimentares e metamorficos na regiao do Quadrilatero Ferrifero, Minas Gerais. Sao Paulo, 127p. (Tese de Doutoramento, Institute de Geociencias, Universidade de Sao Paulo).

O'Connor, J. T. 1965. Classification for quartz-rich igneous rocks based on feldspar ratios. U. S. Geological Survey Professional Paper, 525(B): $79-84$

Pearce, J. A. 1982. Trace element characteristics of lavas from destructive plate boundaries. In: THORPE, R. S. (Ed.), Andesites. Orogenic andesites and related rocks. Chichester, J. Wiley \& Sons, p. 525-547.

Pearce, J. A. 1983. Role of the Sub-continental Lithosphere in Magma Genesis at Active Continental Margins. In: Hawkesworth, C. J. \& Norry, M. J. (Eds), Continental Basalts and Mantle Xenoliths. Nantwich, Shiva, p. 230-349.

Pearce, J. A.; Harris, N. B. W.; Tinddle, A. G. 1984. Trace Element Discrimination Diagrams for the Tectonic Interpretation of Granitic Rocks. Journal of Geology, 25(4):956-983.

Rapp, R. R.; Watson, E. B.; Miller, C. F. 1991. Partial melting of amphibolite/eclogite and the origin of Archaean trondhjemites and tonalites. Precambrian Research, 51:1-25.

Robb, L. J.; Davis, D. W.; Kamo, S. L., Meyer, F. M. 1992. Ages of altered granites adjoing the Witwatersrand Basin with implications for the origin of gold and uranium. Nature, 357:677-678.

Rollinson, H. R., 1993. Using geochemical data: evaluation, presentation, interpretation. London, Longman. $352 \mathrm{p}$.

Sarkar, G.; Corfu, F.; Paul, D. K.; McNaughton, N. J.; Gupta, S. N.; Bishui, P. K. 1993. Early Archaean crust in Bastar Craton, Central India - a geochemical and isotopic study. Precambrian Research, 62:127-137.

Sato, K.; Tassinari, C. C. G., Kawashita, K.; Petronilho, L., 1995. O metodo geocronologico Sm-Nd no IG/USP e suas aplica96es. Anais da Academia Brasileira de Ciencias, 67(3), 314-336.

Schorscher, H. D.; Santana, F. C.; Polonia, J. C.; Moreira, J. M. P. 1982. Quadrilatero Ferrifero - Minas Gerais State: Rio das Velhas Greenstone Belt and Proterozoic Rocks. In: Internacional Symposium on Archaean and Early Proterozoic Evolution and Metallogenesis, Salvador, 1982. Excursion Annex... Salvador, SBG. 43p.

Stacey, J. S. \& Kramers, J. D. 1975. Approximation of terrestrial lead isotope evolution by a two stage model. Earth and Planetary Science Letters, 26:207-221.

Steiger, R. H. \& Jaeger, E. 1978. Subcomission on Geochronology: Convention on the use of Decay Constants in Geochronology and Comoschronology. Contributions to the Geologic Time Scale. Studies. Geology, 6:67-72

Teixeira, W.; Carneiro, M. A.; Noce, C. M.; Machado, N. \& Sato, K. 1996. $\mathrm{Pb}, \mathrm{Sr}$ and $\mathrm{Nd}$ isotope constraints on the Archaean evolution of gneissic-granitoid complexes in the southern S5o Francisco Craton, Brazil. Precambrian Research, 78:151-164.

Teixeira, W.; Cordani, U. G.; Nutman, A. P. \& Sato K. 1998. Polyphase Archaean evolution in the Campo Belo Metamorphic Complex, Southern Sao Francisco Craton, Brazil: SHRIMP U-Pb zircon evidence. Journal of South America Earth Science (in press).

Wiedenbeck, M. \& Watkins, K. P. 1993. A time scale for granitoid emplacement in the Archaean Murchison Province, Western Australia, by single zircon geochronology. Precambrian Research, 61:1-26.

Winchester, J. A. \& Floyd, P. A. 1977. Geochemical discrimination of different magma series and their differentiation products using immobile elements. Chemical Geology, 20:325-343.

Manuscrito A-989

Recebido em 15 de Janeiro de 1998 Revisao dos autores em 15 de junho de 1998 Revisao aceita em 20 de junho de 1998 